\title{
Structural Acceptance Criteria Remote Handling Building Tritium Extraction Facility
}

by

G. Mertz

Westinghouse Savannah River Company

Savannah River Site

Aiken, South Carolina 29808

R. L. Bandyopadhyay

RECEIVED

JAN 102000

O STI

This paper was prepared in connection with work done under the above contract number with the U. S. Department of Energy. By acceptance of this paper, the publisher and/or recipient acknowledges the U.S.

Government's right to retain a nonexclusive, royalty-free license in and to any copyright covering this paper, along with the right to reproduce and to authorize others to reproduce all or part of the copyrighted paper. 
WSRC-TR-99-00251

Rev 0

\title{
STRUCTURAL ACCEPTANCE CRITERIA
}

\author{
REMOTE HANDLING BUILDING \\ TRITIUM EXTRACTION FACILITY (U)
}

September 30, 1999

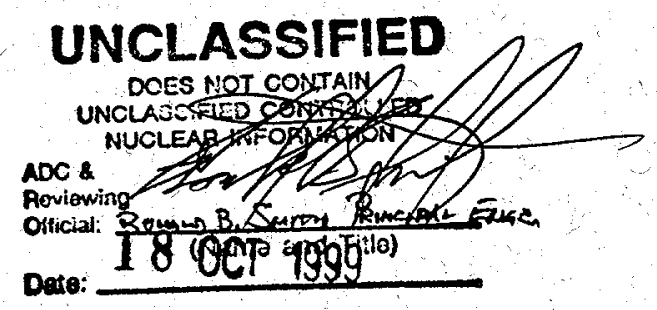

Structural Mechanics

Westinghouse Savannah River Company

Savannah River Site

Aiken, SC 29808

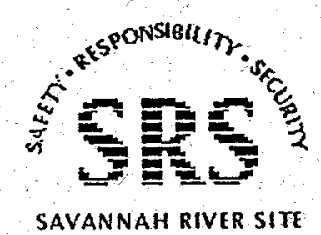




\title{
STRUCTURAL ACCEPTANCE CRITERIA
}

\author{
REMOTE HANDLING BUILDING \\ TRITIUM EXTRACTION FACILITY (U) \\ Final Report
}

By

Ranjit L. Bandyopadhyay

Greg E. Mertz

Technical Reviewers:
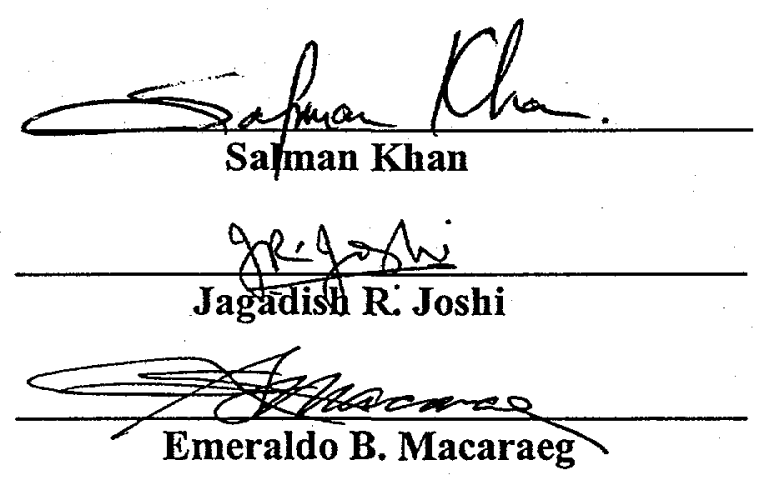

Approved by:

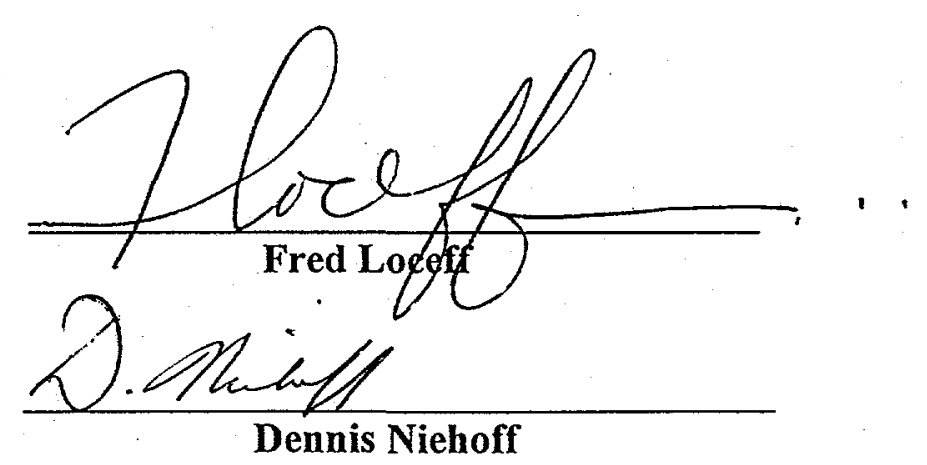




\section{DISCLAIMER}

This report was prepared as an account of work sponsored by an agency of the United States Government. Neither the United States Government nor any agency thereof, nor any of their employees, makes any warranty, express or implied, or assumes any legal liability or responsibility for the accuracy, completeness, or usefulness of any information, apparatus, product, or process disclosed, or represents that its use would not infringe privately owned rights. Reference herein to any specific commercial product, process, or service by trade name, trademark, manufacturer, or otherwise does not necessarily constitute or imply its endorsement, recommendation, or favoring by the United States Government or any agency thereof. The views and opinions of authors expressed herein do not necessarily state or reflect those of the United States Government or any agency thereof.

This report has been reproduced directly from the best available copy.

Available to DOE and DOE contractors from the Office of Scientific and Technical Information, P.O. Box 62, Oak Ridge, TN 37831; prices available from (615) 576-8401.

Available to the public from the National Technical Information Service, U.S. Department of Commerce; 5285 Port Royal Road, Springfield, VA 22161. 


\section{DISCLAIMER}

Portions of this document may be illegible in electronic image products. Images are produced from the best available original document. 
1. INTRODUCTION ? 6

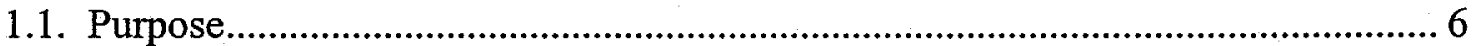

1.2. Scope

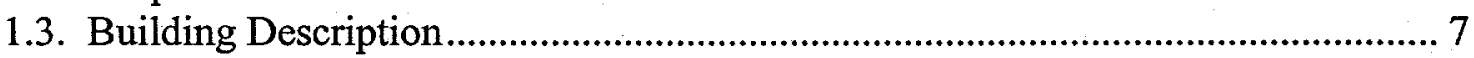

1.4. Performance Category ...................................................................................... 7

1.4.1. Concrete Structure ....................................................................................... 7

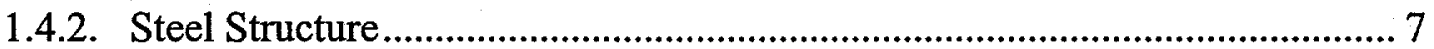

2. DOE ORDER APPLICABILITY.....................................................................11

3. CODES AND STANDARDS.............................................................................12

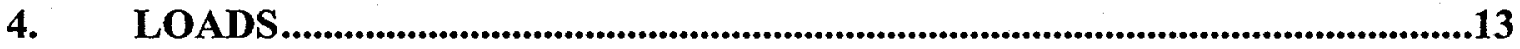

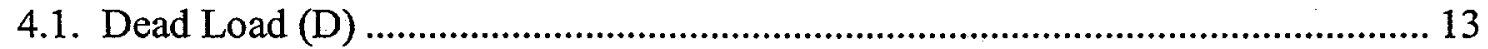

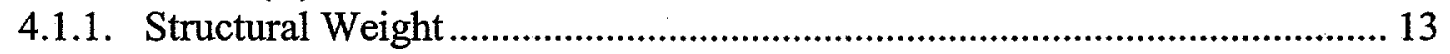

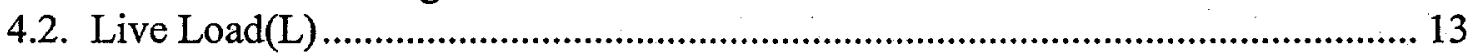

4.2.1. Collateral Load...................................................................................... 13

4.2.2. Major Equipment ....................................................................................... 13

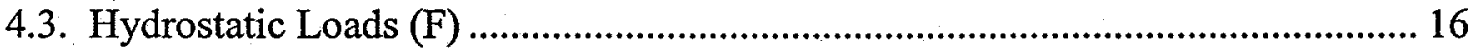

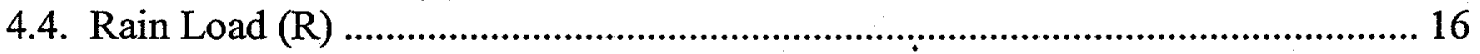

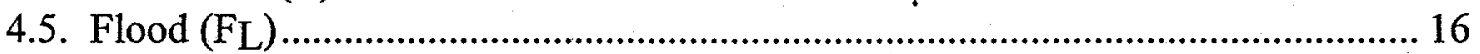

4.6. Snow Load (S) .............................................................................................. 17

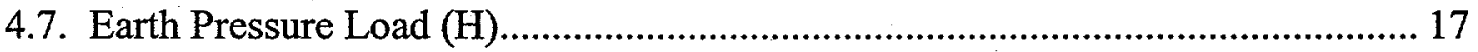

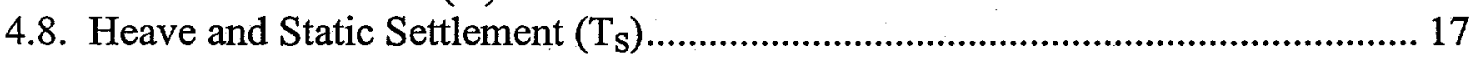

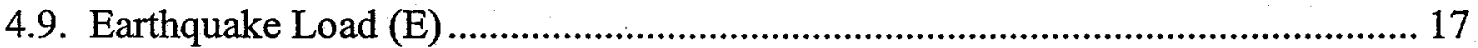

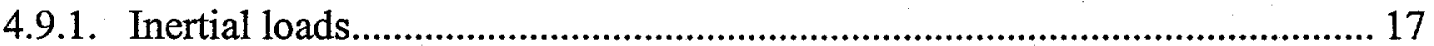

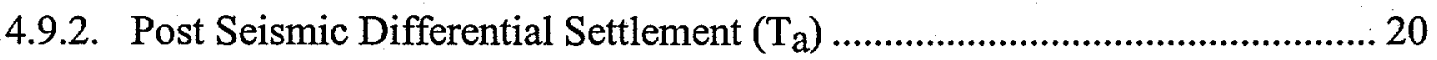

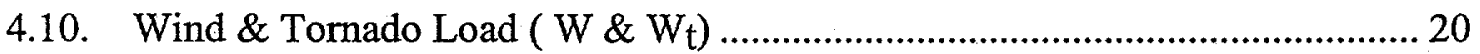

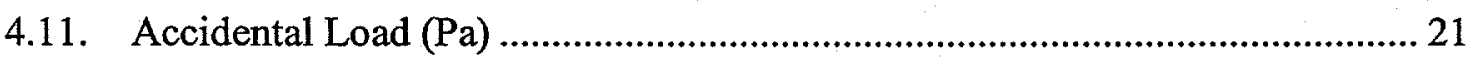

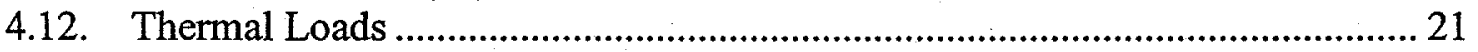

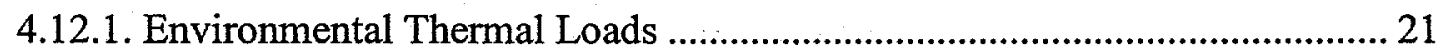

4.12.2. Operational Thermal Loads ....................................................................... 22

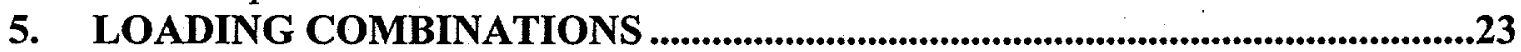

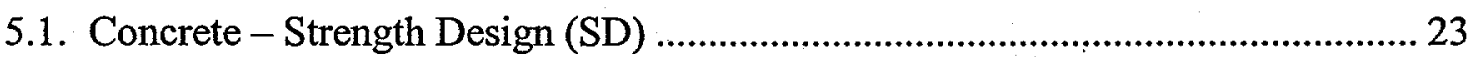

5.2. Steel - Load \& Resistance Factor Design (LRFD) .................................................. 24

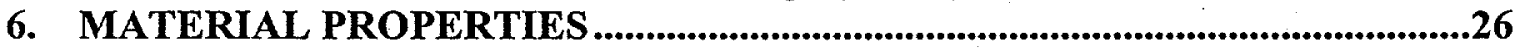

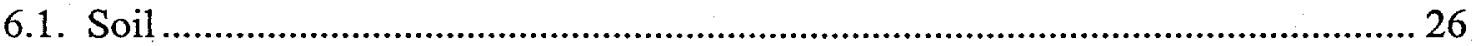

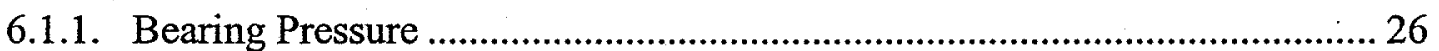

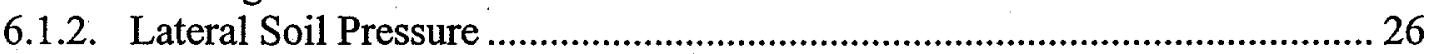

6.1.3. Subgrade Modulus ...................................................................................... 28

6.1.4. Soil Profile and Dynamic Soil Properties ................................................... 28

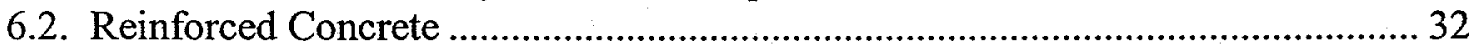

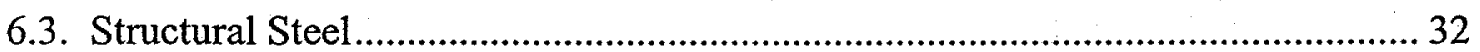

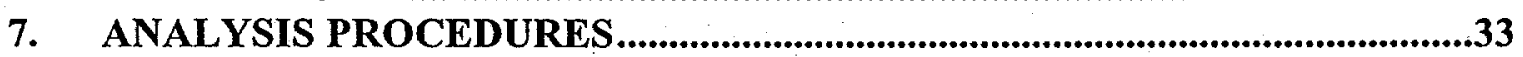

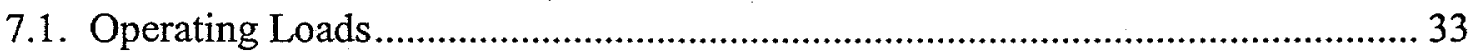

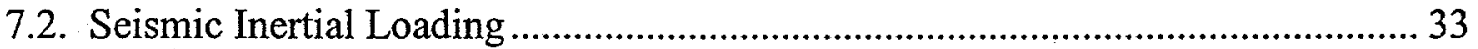

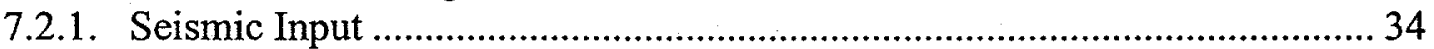




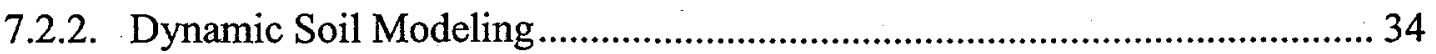

7.2.3. Structural Properties................................................................................. 35

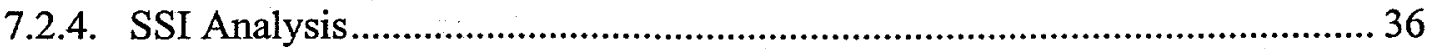

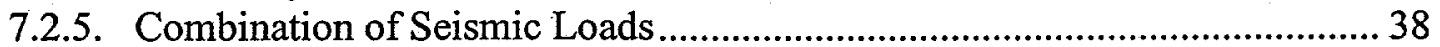

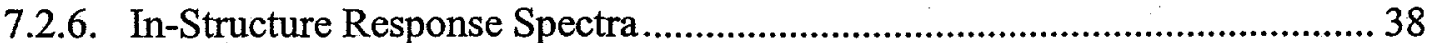

7.3. Post Seismic Differential Settlement ...................................................................... 39

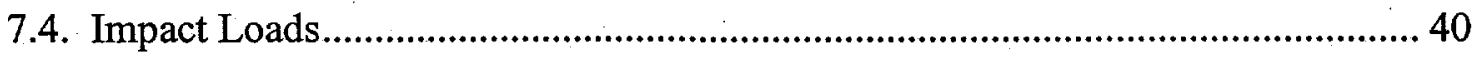

8. STRUCTURAL ACCEPTANCE CRITERIA …..................................................41

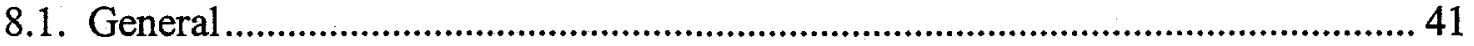

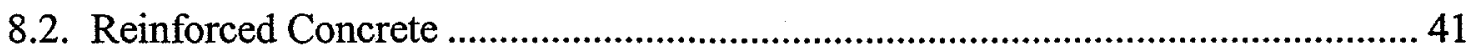

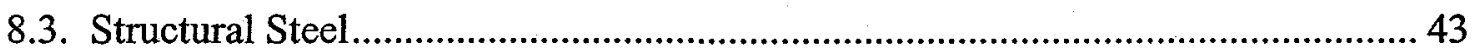

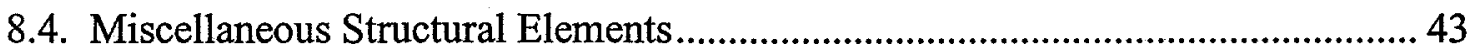

8.4.1. Slab and Wall Moment Frame Detailing Requirements .................................. 43

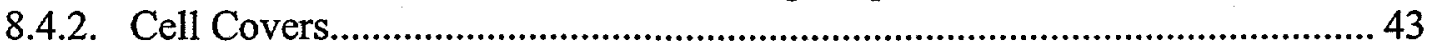

8.4.3. Crane Runway Lateral Support.............................................................. 44

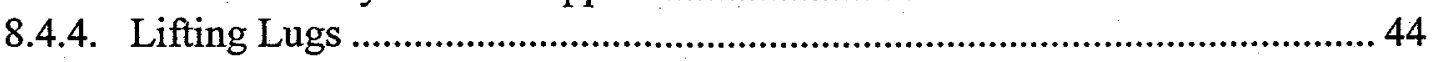

9. REFERENCES.................................................................................................................45 


\section{INTRODUCTION}

\subsection{Purpose}

This structural acceptance criteria contains the requirements for the structural analysis and design of the Remote Handling Building (RHB) in the Tritium Extraction Facility (TEF). The purpose of this acceptance criteria is to identify the specific criteria and methods that will ensure a structurally robust building that will safely perform its intended function and comply with the applicable Department of Energy (DOE) structural requirements.

\subsection{Scope}

These criteria apply to the design of the Remote Handling Building (RHB) in the TEF complex for operating and natural phenomena hazard loads. In addition to qualifying the building structure for appropriate performance category, interaction effects from adjacent buildings or structures of lower PC levels, if any, shall be mitigated.

Natural Phenomena Hazard (NPH) loads include:

- straight wind and hurricanes;

- tornado wind loads and atmospheric pressure drop;

- tornado generated missiles;

- seismic; including hydrodynamic effects, soil structure interaction (SSI) effects, and structure-soil-structure interaction effects;

- seismically induced geological settlement of the building foundation; and

- flood.

DOE Order 420.1 and its associated DOE Standards are implemented at Savannah River Site (SRS) through the site Engineering Standard 01060 (SRS 01060) [4]. Criteria, requirements and procedures given in this document, broadly follow SRS 01060 except as noted herein. The load combinations from SRS 01060 are reduced to applicable controlling load combinations for the RHB. In case of conflict between SRS standards and these criteria, guidelines in these criteria shall govern.

Structural analyses will determine demands acting on the structure in terms of forces and deformations. The capacity of the structure will be determined using the applicable codes allowed in this criteria statement. In all cases the demand at a section will be less than or equal to the capacity of that section. Non-linear analysis may be used to redistribute demand provided that serviceability conditions, including limits on deflections, are met. 


\subsection{Building Description}

The Remote Handling Building (RHB) is a box shaped structure, with plan dimension of approximately $215 \mathrm{ft}$ by $83 \mathrm{ft}$., as shown in Figure 1 . The building is approximately $86 \mathrm{ft}$ tall of which about $30-\mathrm{ft}$ is embedded in the soil, as shown in Figure 2. The walls, foundation and roof are of reinforced concrete, and form a protective barrier for equipment against any external hazards from seismic, wind, tornado and floods. At its east end, the RHB has an above grade steel frame truck bay.

A lighter reinforced concrete processing building is located adjacent to north end of the RHB and is founded on the surface. A chiller building, nitrogen tanks and stack are also located around the RHB.

\subsection{Performance Category}

The Performance Category (PC) of the structure is specified in System Design Description (SDD) [14].

\subsubsection{Concrete Structure}

The SDD specifies that all exterior and interior structural walls, load bearing structures, building foundations, and interior structures and walls providing radiation shielding shall be designed as PC-3 structures. All building systems, structures and components (SSC) that are not part of the primary load path, nor designated as PC-3, shall be designed as PC-2.

The failure of a PC-2 SSC shall not cause failure of the PC-3 structure.

Since the vast majority of poured-in-place reinforced-concrete elements in the RHB are PC-3, all of these components will be designed as PC-3.

\subsubsection{Steel Structure}

The SDD specifies the truck bay enclosure and the associated crane support structure as PC-2. If designed as a PC-2 structure, the truck bay enclosure, which supports a 125-ton crane, may not be able to withstand PC3 tornado loads, PC3 tornado generated missiles, or PC-3 earthquake forces. Then, the PC-3 floor, the removable hatches above the Cask Decon Area and the casks themselves would have to be designed for collapse of the truck bay along with a 125-ton crane drop.

Alternately, the primary structural members (i.e. the members that comprise the primary load path for all loads) and crane support beams could be designed to PC-3 loading, while the secondary members (i.e. purlins and girts) and the cladding could be designed to PC-2 loading. Then, the primary structure would be able to withstand PC3 tornado and PC-3 earthquake forces, while the floor above the cask decon area, and most importantly the casks themselves would not have to be designed to maintain structural integrity for collapse of the truck bay and the impact from a 125 ton crane drop. 
The second approach is adopted in this criteria. Thus, the primary building frames, lateral wind bracing and the crane support structures shall be designed to resist PC-3 loads, while the secondary members and cladding will be designed to resist PC-2 loads. The PC-3 members shall be designed such that:

- The PC-3 members shall be designed for the forces delivered to the system assuming that the PC-2 members do not fail.

- Credit shall not be taken for the lateral support of PC-3 members by PC-2 members. 


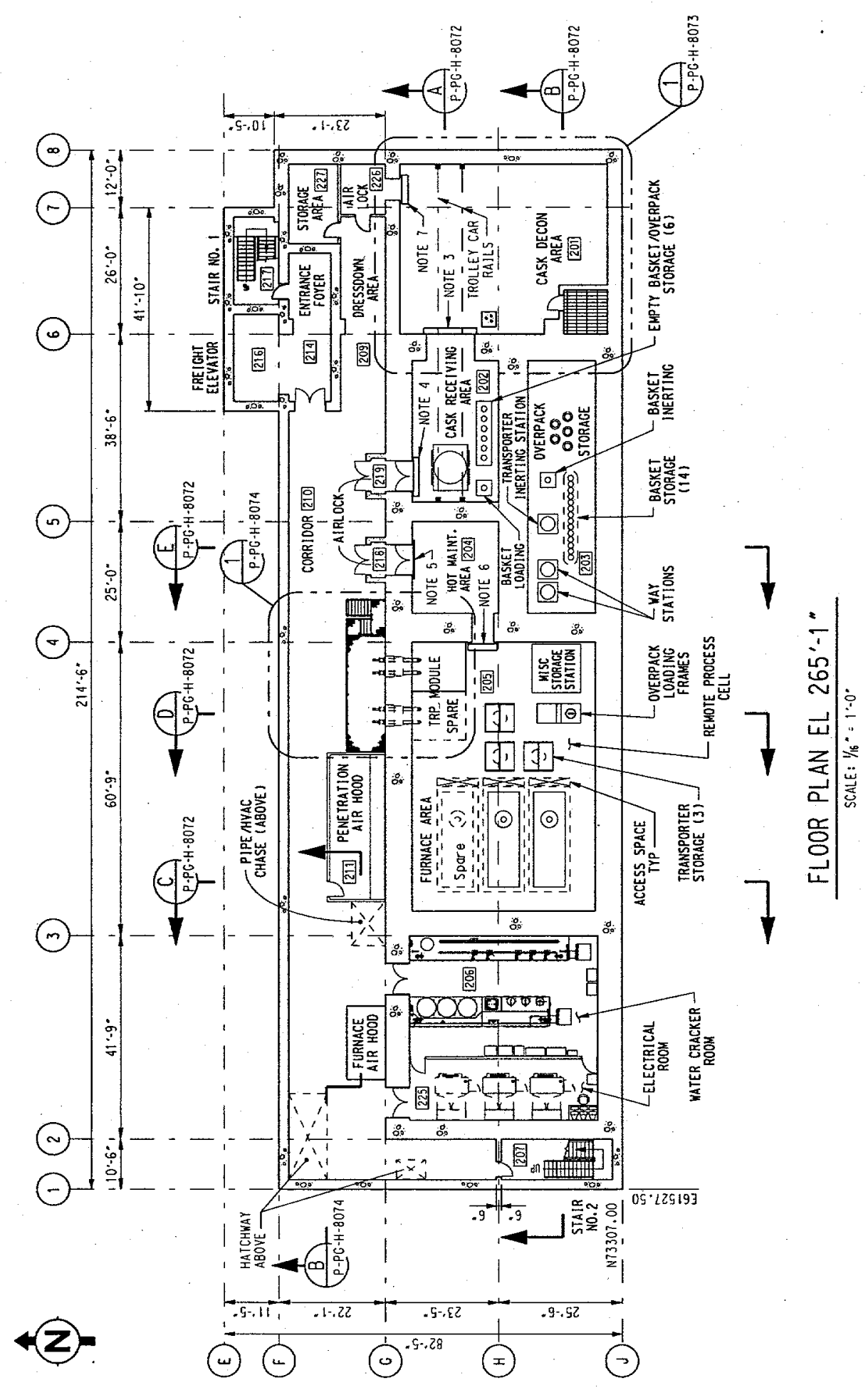

Figure 1 Remote Handling Building - Plan View 


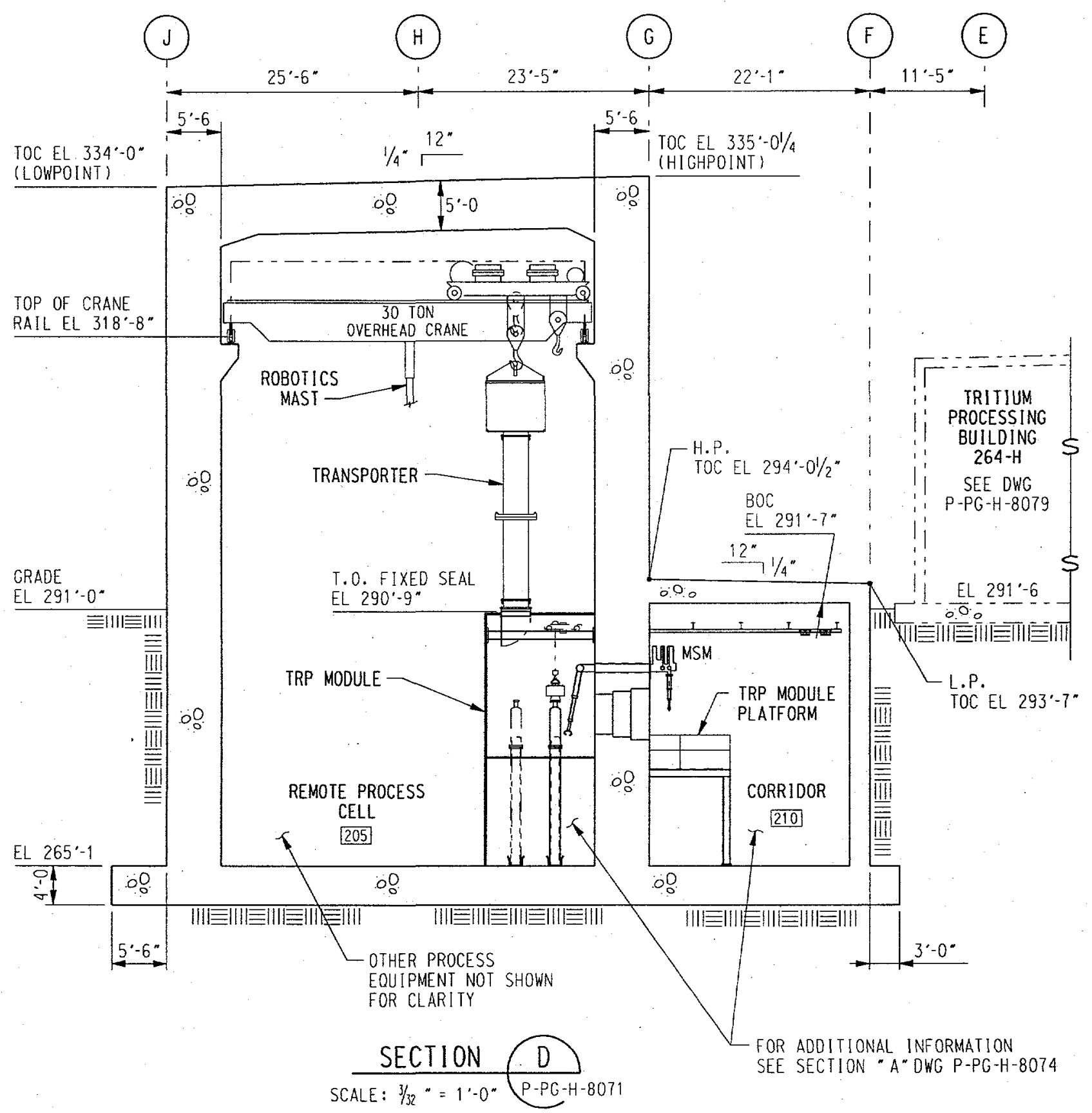

Figure 2 Remote Handling Building - Cross Section 
WESTINGHOUSE SAVANNAH RIVER COMPANY

WSRC-TR-99-00251

TRITIUM EXTRACTION FACILITY

REVISION 0

REMOTE HANDLING BUILDING

$09 / 30 / 99$

STRUCTURAL ACCEPTANCE CRITERIA

PAGE 11 of 45

\section{DOE ORDER APPLICABILITY}

The design of the Tritium Extraction Facility Remote Handling Building shall be in accordance with DOE Order 420.1 Change 2, "Facility Safety" 10/24/96. 


\section{CODES AND STANDARDS}

Except as modified or amended by these criteria, the structural analysis and design of the RHB shall be performed in accordance with the requirements given in the following codes and standards:

- "Structural Design Criteria, Engineering Standard 01060", Draft Rev 4, Savannah River Site, Aiken, SC 29808 (October, 1999) [2].

- DOE-STD-1020, "Natural Phenomenon Hazards Design and Evaluation Criteria for Department of Energy Facilities" [1].

- ACI 318-99, "Building Code Requirements for Structural Concrete" [4]. Except portions of ACI 349-97, "Code Requirements for Nuclear Safety Related Concrete Structures" [5] shall be used as delineated in Section 8 of this criteria.

- ASCE Standard 4-86, "Seismic Analysis of Safety Related Nuclear Structures and Commentary on Standard for Seismic Analysis of Safety Related Nuclear Structures", American Society of Civil Engineers [6].

- "Manual of Steel Construction, Load \& Resistance Factor Design (LRFD)", Volume I and II, Second Edition [7].

- Portions of AISE Technical Report No. 13, "Guide for the Design and Construction of Mill Buildings", Association of Iron \& Steel Engineers, 1991 [10] shall be used for the design of crane runway girders and stepped crane columns as delineated in Section 8 of this criteria.

- ASCE Manual No. 58, "Structural Analysis and Design of Nuclear Plant Facilities", [24]. 


\section{LOADS}

The structural components of the RHB shall be evaluated for the loads specified in this section.

\subsection{Dead Load (D)}

\subsubsection{Structural Weight}

Dead load calculation shall be based on the following unit weights :

$\begin{array}{lc}\text { Reinforced concrete } & 150 \mathrm{pcf} \\ \text { Structural steel } & 490 \mathrm{pcf} \\ \text { Backfill and earth cover } & 125 \mathrm{pcf} \\ \text { Water } & 62.4 \mathrm{pcf} \\ \text { Roofing } & 10 \mathrm{psf} \\ \text { Steel truck bay - steel super- } & 15 \mathrm{psf} \\ \quad \text { structure dead weight } & \end{array}$

Roofing and superstructure dead weights shall be applied to the projected roof area.

\subsubsection{Collateral Load}

A 50 psf collateral load for suspended piping, conduits, HVAC equipment, ceilings etc., is included as a dead load. One half of this collateral load (25 psf) shall be considered to act concurrently with seismic loads.

\subsubsection{Major Stationary Equipment}

The weight of major stationary equipment was developed in Reference 13. The maximum equipment load of 900 psf, distributed over the equipmemt footprint, is due to a loaded transporter docked at the way station. A uniform floor dead load of $1000 \mathrm{psf}$ is used to bound this distributed load as shown in Table 1.

The dead loads in Table 1 bound the actual equipment weights. The equipment weights in Reference 13 combined with an additional 25 psf floor dead load shall be considered to act concurrently with seismic loads. 
Table 1 Dead Loads In RHB

$\begin{array}{cllc}\begin{array}{c}\text { Approximate } \\ \text { Elevation }\end{array} & \text { Room No. } & \text { Room } & \text { Dead Load } \\ \text { Ft } & & & \text { psf } \\ 265 & 201 & \text { Cask decon area } & 1000 \\ 265 & 202 & \text { Cask receiving area } & 1000 \\ 265 & 203 & \text { Overpack storage } & 1000 \\ 265 & 205 & \text { Furnace area } & 1000 \\ 265 & 206 & \text { Water cracker } & 1000\end{array}$

\subsection{Live Load(L)}

Live loads for the RHB are defined in this section as the summation of the floor live load, mobile equipment loads, and an external crane access load.

\subsubsection{Floor Live Load}

Conservative uniform live loads are given in this section to bound personnel, partition and mobile equipment loads. Live loads for different rooms are tabulated in Table 3. Concentrated live loads due to cranes, casks, shields and the delivery vehicle, in Table 6, are applied in addition to the distributed live load.

The truck bay floor and hatches shall be designed for (1) the concentrated cask and transport vehicle loads in Table 3 with a 100 psf live load; and (2) the 1000 psf live load in Table 3 . However, these two live load cases are not considered simultaneously.

The live load acting on internal cell covers (hatches) shall be the greater of the uniform live load or the weight of two additional cell covers.

Crane and hoist loads[10] shall be considered in the design as live loads. Vertical crane and hoist loads shall be increased by $25 \%$ for impact. The total side thrust shall be distributed with due regard for the lateral stiffness of the structures supporting the rails and shall be the greatest of:

- $40 \%$ of the lifted load;

- $20 \%$ of the combined weight of the lifted load, trolley and other lifting devices, i.e. spreader beam, hook block, rotating mechanism etc.; or

- $10 \%$ of the combined total weight of the lifted load and the crane weight.

The tractive force shall be $20 \%$ of the maximum load on driving wheels. The side thrust and the tractive forces shall not be considered with Earthquake loads $(\mathrm{E})$, or Tornado loads $\left(\mathrm{W}_{\mathrm{t}}\right)$.

All of the mobile equipment weight shall be considered to act concurrently with seismic loads. Lifted crane loads shall not be considered to act concurrently with seismic loads. 
A floor live load of $50 \mathrm{psf}$ and the mobile equipment in Table 3 shall be considered to act concurrently with seismic loads. This live load accounts for personnel, partitions and miscellaneous equipment not listed in Table 2.

\section{Table 2 Live Loads In RHB}

$\begin{array}{cllr}\begin{array}{c}\text { Approximate } \\ \text { Elevation }\end{array} & \text { Room No. } & \text { Room } & \text { Live Load } \\ \text { Ft } & & & \text { psf } \\ 347 & 215 & \text { Truck bay roof } & 30 \\ 335,346 & & \text { Concrete roof } & 100 \\ 335 & 216 & \text { Freight elevator roof } & 100 \\ 335 & 207,217 & \text { Stair \#1 \& \#2 roof } & 100 \\ 308 & 221 & \text { Crane maintenance room } & 250 \\ 292 & 220 & \text { HEPA filter room } & 100 \\ 292 & 204,202 & \text { Hot maintenance hatch } & 1000 \\ 292 & 204,202 & \text { Hatches between G4 \& H5, and H4 and J6. } & 1000 \\ 265 & 116,117 & \text { Corridor } & 100 \\ & 212 & \text { Corridor chase } & 250 \\ 294 & 210 & \text { Corridor roof } & 250 \\ 265 & 210 & \text { Corridor floor } & 250 \\ 295 & 215 & \text { Truck bay floor and hatches } & 1000 \\ 265 & 206 & \text { Water cracker } & 250 \\ 265 & 205 & \text { Furnace area } & 250 \\ 265 & 204 & \text { Hot maintenance area } & 1000 \\ 265 & 202 & \text { Cask receiving area } & 250 \\ 265 & 203 & \text { Overpack storage } & 250 \\ 265 & 201 & \text { Cask decon area } & 250 \\ 265 & 227 & \text { Storage } & 250 \\ 265 & 209,214,226 & \text { Airlock/dressdown \& entrance area } & 250 \\ 265 & 211 & \text { Penetration air hood } & 250 \\ & 207,217 & \text { Stairs \#1 \& \#2 } & 100\end{array}$


Table 3- Mobile Equipment

\section{Item Equipment}

10. $\quad 125$ Ton Crane

1130 Ton Crane and Trolley

12 Cask Receiving/Cask Decon Shield

Door

13 Cask Receiving/Corridor Shield Door

14 Hot Maintenance/ Corridor Shield Door

15 Hot Maintenance/ RHA Shield Door

16 Crane Maintenance Shield Door

17 Railroad Cask

18 LWT Cask

19 Cask Delivery Vehicle

20. Cask Trolley Car
Weight

$136.8 \mathrm{kip}$

$87.4 \mathrm{kip}$

200 kip

36 kip

8 kip

26 kip

$290 \mathrm{kip}$

250 kip

60 kip

Undefined

Undefined

\section{Distributed Load} 00023 Draft Section

5.1

5.2

5.10

5.10

5.10

5.10

5.10

5.11

5.11

5.11

\subsubsection{External Crane Access Live Load}

A fully loaded 250 Ton crane (Manitowoc 4100) shall be assumed to be located adjacent to each external basement wall. On the North basement wall, the crane and processing building weight shall be considered separately.

The crane access live load does not act concurrently with seismic loads.

\subsection{Hydrostatic Loads $(F)$}

The design water table for the building is at elevation 260 feet [11]. Hydrostatic loads shall be considered on elements below this elevation. The sump inside the building, which collects contaminated water, shall be designed for internal hydrostatic loads.

\subsection{Rain Load (R)}

The roof has positive drainage, which precludes the accumulation of rainwater. Thus, rain loads are enveloped by live loads and are not considered explicitly.

\subsection{Flood $\left(F_{\nu}\right)$}

The RHB lies outside of the PC-3 flood plane (10,000 year return period) [15]. Thus, floods are not considered in the design of the RHB. 


\subsection{Snow Load (S)}

The ground snow load for SRS given in ASCE 7-95 [3] is 5 psf. Even with an importance factor of 1.2 , the snow loads are enveloped by roof live loads and are not considered.

\subsection{Earth Pressure Load (H)}

Lateral earth pressure on walls shall be computed using the coefficient of lateral earth pressure at-rest. The effects of consolidation on the lateral soil pressure shall be included. The effects of loads from adjacent structures shall also be included.

\subsection{Heave and Static Settlement $\left(T_{s}\right)$}

Geotechnical investigations [11] have determined that the soil under the RHB could heave up to 2 inches during excavation. Since the weight of the RHB is similar to the excavated soil, the soil will recompress during construction.

An additional $1 / 2$ inch of secondary consolidation is expected. Differential settlements are taken as $1 / 2$ of the total settlement.

\subsection{Earthquake Load (E)}

Both inertial earthquake loads and seismically induced differential settlement are considered.

\subsubsection{Inertial loads}

The TEF PC-3 free field surface design response spectra, defined by SRS 01060 , is given in Table 4 and shown in Figure 3. This spectra has been reviewed and accepted for the TEF site by SRS Site Geotechnical Services [11]. At 5\% damping, the peak free field acceleration, velocity and displacement are $0.375 \mathrm{~g}$, $17 \mathrm{inch} / \mathrm{sec}$ and $7.7 \mathrm{inches,}$ respectively. The vertical spectra shall be two thirds of the horizontal spectra. 
Table 4 TEF PC-3 Free Field Surface Design Response Spectra, Digitized Values [22]

Frequency (Hz)

Spectral Acceleration ( $g$ )

$\begin{array}{cccccc} & \begin{array}{c}\mathbf{2 \%} \\ \text { Damping }\end{array} & \begin{array}{c}\mathbf{4 \%} \\ \text { Damping }\end{array} & \begin{array}{c}\mathbf{5 \%} \\ \text { Damping }\end{array} & \begin{array}{c}\mathbf{7 \%} \\ \text { Damping }\end{array} & \begin{array}{c}\mathbf{1 0 \%} \\ \text { Damping }\end{array} \\ 0.10 & 0.0122 & 0.0087 & 0.0075 & 0.0070 & 0.0067 \\ 0.20 & 0.0344 & 0.0316 & 0.0300 & 0.0287 & 0.0258 \\ 0.25 & 0.0614 & 0.0533 & 0.0490 & 0.0483 & 0.0440 \\ 0.30 & 0.0844 & 0.0718 & 0.0650 & 0.0648 & 0.0589 \\ 0.35 & 0.1055 & 0.0919 & 0.0850 & 0.0798 & 0.0732 \\ 0.40 & 0.1265 & 0.1114 & 0.1040 & 0.0950 & 0.0856 \\ 0.45 & 0.1483 & 0.1300 & 0.1210 & 0.1102 & 0.0985 \\ 0.50 & 0.1662 & 0.1451 & 0.1350 & 0.1228 & 0.1100 \\ 0.60 & 0.1990 & 0.1780 & 0.1677 & 0.1456 & 0.1300 \\ 2.00 & 0.4690 & 0.4050 & 0.3750 & 0.3360 & 0.2982 \\ 9.00 & 0.4690 & 0.4050 & 0.3750 & 0.3360 & 0.2982 \\ 33.00 & 0.1600 & 0.1600 & 0.1600 & 0.1600 & 0.1600 \\ 100.00 & 0.1600 & 0.1600 & 0.1600 & 0.1600 & 0.1600\end{array}$

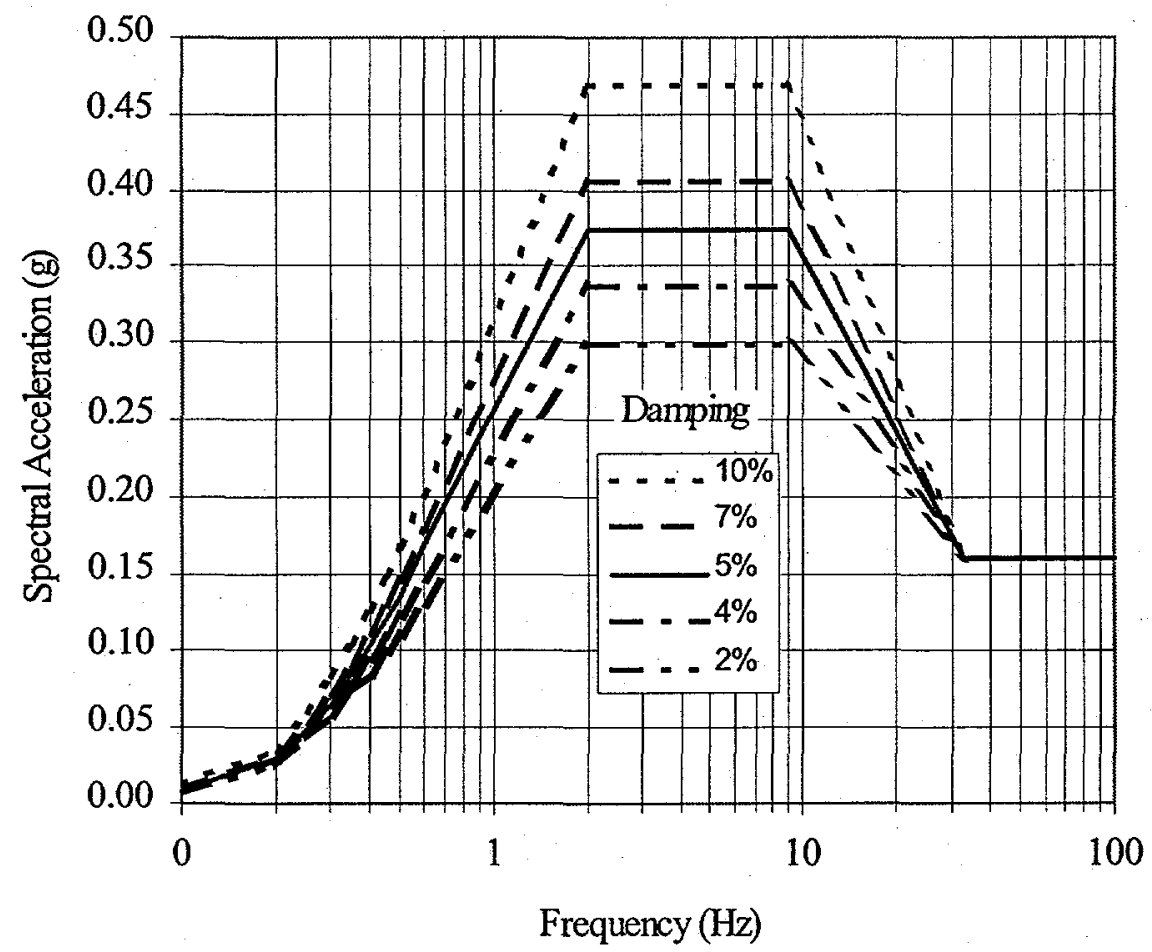

Figure 3A PC-3 Free Field Surface Design Response Spectra 


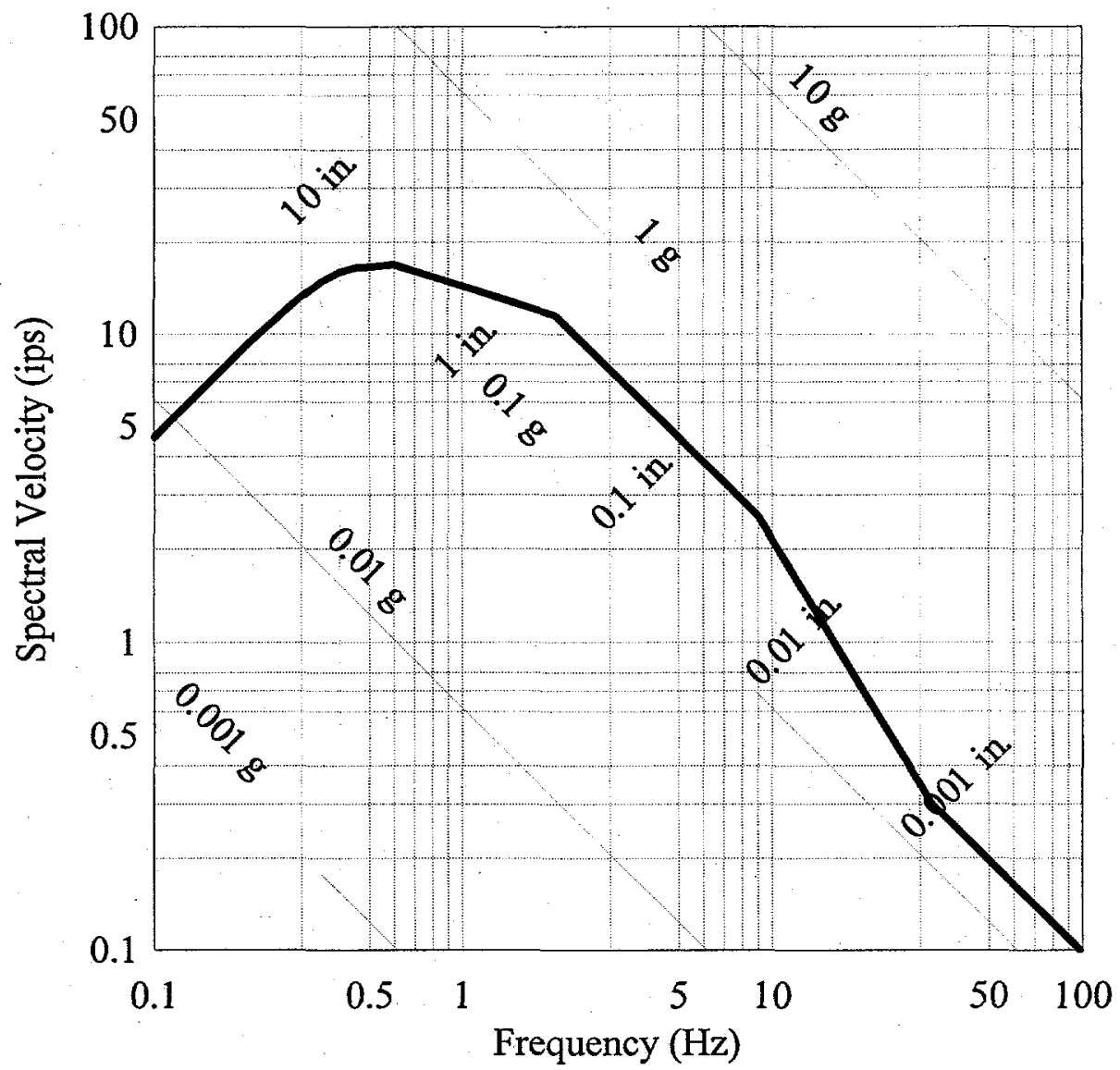

Figure 3B TEF PC-3 Free Field Surface Design Response Spectra Spectral Velocity $-5 \%$ Damping

The TEF PC3 design input spectra, corresponding to 5 percent damping shall be used to develop independent orthogonal time histories. The motion duration characteristics summarized in Table 5 shall be used to produce random phased artificial ground time history motions. This earthquake duration correspond to a $\mathrm{Mw}=7$ to 7.5 earthquake as given in the 1997 Draft of ASCE 4 [17].

Table 5 Duration Enveloping Function for Seismic Motion

$\begin{array}{lr}\text { Rise Time } & 2 \text { seconds } \\ \text { Duration of Strong Motion } & 13 \text { seconds } \\ \text { Decay Time } & 9 \text { seconds }\end{array}$

Consistent with the requirements of SRS 01060, earthquake loads on concrete and steel structures are increased by twenty percent through a load factor in the 
loading combinations specified in Section 5.0. Earthquake loads on mechanical systems and components shall be increased by twenty percent either through amplification of in-structure response spectra or in-structure time histories.

ASCE 4-86 shall be used to develop the lateral seismic loads on embedded walls. The seismic demand from earth pressure against concrete walls shall be added to the static soil pressure demands.

\subsubsection{Post Seismic Differential Settlement $\left(T_{2}\right)$}

Liquefaction and the subsidence of soft zones during a seismic event can cause localized settlement below the base of RHB. Geotechnical investigations [11] have identified a $40^{\prime}$ diameter soft zone at a depth of 143' under the RHB and, through analysis, have determined that soft zone subsidence could result in a settlement of up to one inch.

Liquefaction analyses [11] indicate $1 / 2$ " to 1 " of dynamic settlement under the RHB. However, liquefaction analyses of the TEF site indicate dynamic settlements ranging up to 3" at a location north of the RHB. SRS Site Geotechnical Services has recommend that the differential settlement due to liquefaction be applied to the remote handling building over the width of the basemat ( 70 feet).

Consistent with the requirements of SRS 01060, post seismic differential settlements are also increased by $20 \%$.

The post seismic internal differential settlement shall not be considered to occur concurrently with seismic inertial loads as defined above.

\subsection{Wind \& Tornado Load $(W \& W$ )}

Loads from wind and tornado shall be calculated as per ASCE 7-95 [3] using the guidance of DOE-STD-1020 [1]. The wind and tornado characteristic in Table 6, which are based on SRS 01060, shall be used. Per DOE-STD-1020 [1], Exposure Category C and an Importance Factor of 1.0 are used along with ASCE 7 [3] to calculate the wind and tornado forces acting on the building. 
Table 6 - Wind \& Tornado Characteristic

\begin{tabular}{|c|c|c|c|}
\hline & $\begin{array}{l}\text { Performance } \\
\text { Category }\end{array}$ & $\overline{P C-2}$ & PC-3 \\
\hline \multirow{3}{*}{$\begin{array}{l}\mathbf{W} \\
\text { I } \\
\mathbf{N} \\
\text { D }\end{array}$} & $\begin{array}{l}\text { Annual Hazard } \\
\text { Exceedance } \\
\text { Probability }\end{array}$ & $1 \times 10^{-2}$ & $1 \times 10^{-3}$ \\
\hline & $\begin{array}{l}\text { Three Second Wind, } \\
\text { Speed, } \\
\text { Mph }\end{array}$ & 107 & 133 \\
\hline & Missile Criteria & $\overline{\mathrm{NA}}$ & $\begin{array}{l}2 \times 4 \text { timber plank 15 lb @ } 50 \\
\text { mph (horiz); max height } 30 \mathrm{ft} .\end{array}$ \\
\hline \multirow{4}{*}{$\begin{array}{l}\mathbf{T} \\
\mathbf{O} \\
\mathbf{R} \\
\mathbf{N} \\
\mathbf{A} \\
\mathbf{D} \\
\mathbf{O}\end{array}$} & $\begin{array}{l}\text { Annual Hazard } \\
\text { Exceedance } \\
\text { Probability }\end{array}$ & NA & $2 \times 10^{-5}$ \\
\hline & $\begin{array}{l}\text { Three Second Wind } \\
\text { Speed, mph }\end{array}$ & $\mathrm{NA}$ & 178 \\
\hline & $\begin{array}{l}\text { Atmospheric Pressure } \\
\text { Change (APC) }\end{array}$ & $\overline{\mathrm{NA}}$ & 70 psf@30 psf/sec \\
\hline & Missile Criteria & NA & $\begin{array}{l}2 \times 4 \text { timber plank } 15 \mathrm{lb} @ 100 \\
\text { mph (horiz); max height } 150 \mathrm{ft} \text {; } \\
70 \mathrm{mph} \text { (vert) } \\
3 \text { in dia std steel pipe, } 751 \mathrm{~b} @ \\
50 \mathrm{mph} \text { (horiz); max height } 75 \\
\mathrm{ft} ; 35 \mathrm{mph} \text { (vert) } \\
3000 \mathrm{lb} \text { automobile @ } 19 \mathrm{mph} \\
\text { rolls and tumbles }\end{array}$ \\
\hline
\end{tabular}

\subsection{Accidental Load (Pa)}

The minimum lateral load on internal walls or partitions shall be 5 psf [18].

\subsection{Thermal Loads}

\subsubsection{Environmental Thermal Loads}

The average monthly high temperature at SRS is less than $95^{\circ} \mathrm{F}$, while the average monthly low temperature is above $35^{\circ} \mathrm{F}$. Experience at SRS has shown that heavy reinforced concrete structures, like the RHB, perform well in this temperature range. Based on this experience, the RHB will not be evaluated for environmental thermal loads. 


\subsubsection{Operational Thermal Loads}

The surface concrete temperature in the furnace area will be less than $150^{\circ} \mathrm{F}$. Thermal loads due to the furnace will not be evaluated further.

The peak concrete temperature at steam line and wall /slab penetrations will be less than $200^{\circ} \mathrm{F}$ as allowed by ACI 349 [5].

Embedment plates in concrete walls and slabs will be sized to include assumed thermal expansion loads generated by piping and equipment. The piping and equipment will then be designed with sufficient flexibility such that the assumed thermal expansion loads are not exceeded. The effects of thermal expansion forces from piping and equipment acting on the RHB structure are not significant and will not be evaluated further. 


\section{LOAD COMBINATIONS}

The following load combinations are adapted from SRS 01060. Load combinations that contain thermal, flood, pipe break, and accident pressure loads are omitted. Load combinations which consider (1) half floor and roof loads; or (2) floor and half roof loads; are simplified into full floor plus full roof load combinations. Similarly, full crane loads are used with full floor and roof loads.

Dead and live loads can reduce the effects of seismic or wind induced overturning. Likewise, dead and live loads can reduce the effects of wind induced uplift on roofs. These effects are considered on specific elements by reducing the dead load by $10 \%$ and neglecting the live load when applicable.

\subsection{Concrete - Strength Design (SD)}

For heavy concrete structures, like the RHB, gravity load combinations and seismic load combinations control the design. Thus, load combinations 1 and 2 shall be considered for the heavy RHB concrete structure.

1. $\mathrm{U}=1.4 \mathrm{D}+1.7 \mathrm{~L}+1.7 \mathrm{H}+1.7 \mathrm{~F}$

2. $\mathrm{U}=1.0 \mathrm{D}+1.0 \mathrm{~L}+1.0 \mathrm{H}+1.0 \mathrm{~F}+1.2 \mathrm{E}$

Notes:

- Load combination 1 represents the full factored dead and live load in $\mathrm{ACl}$ 318.

- Loading combination 2 is based on DOE-STD-1020 which combines the mean loads acting on the structure with the mean seismic load. The 1.2 load factor on seismic in Load Combination 2 represents the 20\% increase in seismic load specified in SRS 01060.

For light reinforced concrete appurtenances, wind and tornado loads may control the design. For these structures load combinations 3 and 4 shall also be considered. In elements where the effects of seismic or wind loads are reduced by dead load, only $90 \%$ of the dead load shall be considered. The beneficial effects of live load shall be neglected in elements where the effects of seismic or wind loads are reduced by live load.

3. $\mathrm{U}=1.0 \mathrm{D}+1.15 \mathrm{~L}+1.15 \mathrm{H}+1.0 \mathrm{~F}+1.15 \mathrm{~W}$

4. $\mathrm{U}=1.0 \mathrm{D}+1.0 \mathrm{~L}+1.0 \mathrm{H}+1.0 \mathrm{~F}+1.0 \mathrm{~W}_{\mathrm{t}}$

Notes:

- Loading combination 3 represents $90 \%$ of the ACI-318 load combination for wind $90 \% \times 0.75(1.4 D+1.7 L+1.7 W)$. DOE-STD-1020 allows a $10 \%$ reduction of load combinations given by the applicable material specific consensus design standards for PC3 straight wind and hurricanes $(W)$.

- Loading combination 4 is given in DOE-STD-1020 for tornado winds (W). 
- PC-3 Tornado wind generates larger out-of-plane loads than PC-3 seismic loads for walls less than 18 inches thick. However, the total base shear acting on the structure due to seismic loads may be larger than tornado wind base shear for walls less than 18 inches thick because seismic base shear is a function of mass and tornado base shear is a function of surface area.

\subsection{Steel - Load \& Resistance Factor Design (LRFD)}

For PC3 steel structures, loading combinations 1 to 4 shall be considered. In members where the effects of seismic or wind loads are reduced by dead load, only $90 \%$ of the dead load shall be considered. The beneficial effects of live load shall be neglected in elements where the effects of seismic or wind loads are reduced by live load.

1. $\mathrm{U}=1.2 \mathrm{D}+1.6 \mathrm{~L}$

2. $\mathrm{U}=1.0 \mathrm{D}+1.0 \mathrm{~L}+1.2 \mathrm{E}$

3. $\mathrm{U}=1.0 \mathrm{D}+1.15 \mathrm{~L}+1.15 \mathrm{~W}$

4. $\mathrm{U}=1.0 \mathrm{D}+1.0 \mathrm{~L}+1.0 \mathrm{~W}_{\mathrm{t}}$

Notes:

- Load combination 1 represents the full factored dead and live load in AISCLRFD.

- Loading combination 2 is based on DOE-STD-1020, which combines the mean gravity loads acting on the structure with the mean seismic load. The 1.2 load factor on seismic in Load Combination 2 represents the 20\% increase in seismic load specified in SRS 01060.

- Loading combination 3 represents $90 \%$ of the AISC-LRFD load combination for wind $90 \%(1.2 D+0.5 L+1.3 W)$. Note that the dead load factor is rounded down to 1.0 and the live load factor is rounded up to 1.15 to avoid confusion with the concrete wind load combination. DOE-STD-1020 allows a $10 \%$ reduction of load combinations given by the applicable material specific consensus design standards for PC3 straight wind and hurricanes (W).

- Loading combination 4 is given in DOE-STD-1020 for tornado winds (Wv).

For light PC- 2 secondary steel elements, loading combinations 5 and 6 shall be considered. In elements where the effects of seismic or wind loads are reduced by dead load, the dead load factor shall be equal to 0.9 . The beneficial effects of live load shall be neglected in elements where the effects of seismic or wind loads are reduced by live load.

5. $\mathrm{U}=1.2 \mathrm{D}+1.6 \mathrm{~L}$

6. $\mathrm{U}=1.2 \mathrm{D}+0.5 \mathrm{~L}+1.3 \mathrm{~W}_{\mathrm{PC}-2}$ 
Wind is the controlling lateral load combination on light low-rise steel structures while seismic is the controlling lateral load combination on heavy low-rise steel structures. In the RHB, the structure supporting the heavy crane is designed to PC-3 loads while the light secondary structural elements and cladding are designed to PC-2 loads. Seismic will not control the design of the secondary structural elements and cladding. The following PC-2 seismic load combination is given for information only.

7. $\mathrm{U}=1.2 \mathrm{D}+0.5 \mathrm{~L}+1.2 \mathrm{E}_{\mathrm{PC}-2}$

Note:

- Load combination 5, 6 and 7 are the load factors for conventional structures given in AISC-LRFD. 


\section{MATERIAL PROPERTIES}

\subsection{Soil}

Soil properties are developed in Reference 11 "Commercial Light Water Reactor, Tritium Extraction Facility, Geotechnical Summary Report". The data contained in this section is extracted from Reference 11, unless otherwise noted.

\subsubsection{Bearing Pressure}

Remote Handling Building (RHB) is a compensated structure, i.e.; the weight of the building is approximately equal to the weight of the excavated soil and the net load on the subsurface foundation soil is near zero.

\subsubsection{Lateral Soil Pressure}

Lateral soil pressure coefficients for at-rest, active and passive pressures are summarized in Table 8 . An embedded wall has to move laterally between $0.5 \%$ to $1 \%$ of the walls height [19] to develop active soil pressure against the retaining wall. The RHB embedded walls are designed for lateral displacements less than $0.5 \%$, thus, the at-rest soil pressure shall be used to develop lateral load acting on an embedded wall.

Lateral soil loads due to compaction, in excess of the at-rest soil pressure, are developed using Duncan's method and are shown in Table 6 and Figure 4 [20]. These soil pressures are based on compaction with a $7^{\prime}$ wide -60 kip roller compactor using $6 "$ lifts. The total pressure acting on the wall after compaction is the sum of the at-rest soil pressure and the incremental lateral soil pressure due to compaction as shown in Figure 4.

A uniform soil density of $125 \mathrm{pcf}$ shall be used to determine lateral soil pressures. 
Table 7: Lateral Soil Pressure $[11,20]$

Coefficient of active earth pressure

Coefficient of lateral earth pressure at-rest

Coefficient of passive earth pressure

Incremental lateral soil pressure due

$\begin{array}{cc}\begin{array}{c}\text { Depth } \\ \text { (feet) }\end{array} & \begin{array}{r}\text { Pressur } \\ \text { (psf) }\end{array} \\ 0 . & 0 \\ 2 . & 492 \\ 4 . & 487 \\ 8 . & 378 \\ 16 . & 140 \\ 20.7 & 0\end{array}$

$\begin{array}{ll}\mathrm{K}_{\mathrm{a}} & 0.29\end{array}$

$\mathrm{K}_{\mathrm{o}} \quad 0.43$

0.46 On-site native soil

$\mathrm{K}_{\mathrm{p}} \quad 3.40$

\section{Compacted fill}

to compaction:

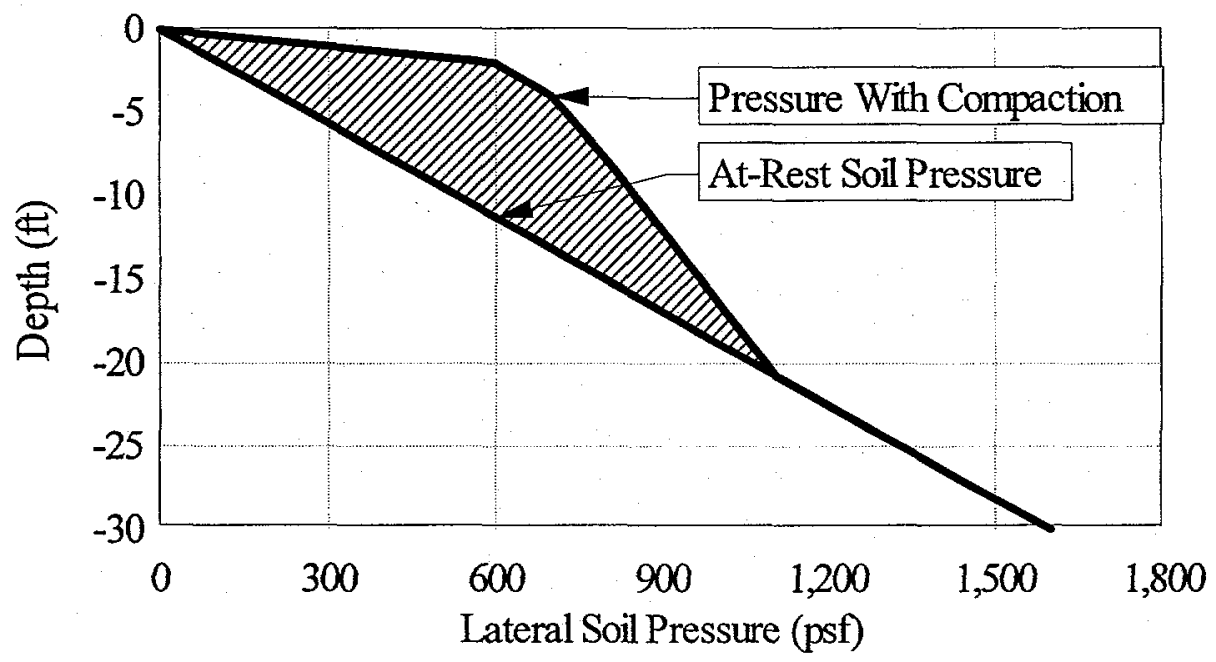

Figure 4 Incremental Lateral Soil Pressure Due To Compaction [20] 


\subsubsection{Subgrade Modulus}

The subgrade modulus for a $1^{\prime} \mathrm{x} 1$ ' plate is $300 \mathrm{ksf} / \mathrm{ft}$ (175 pci). The following scaling law shall be used to determine the subgrade modulus for larger foundations:

$$
\mathrm{K}_{\text {Subgrade }}=\mathrm{K}_{1}\left(\frac{\mathrm{B}+1}{2 \mathrm{~B}}\right)^{2}
$$

where $\mathrm{B}$ is the width of the foundation in feet, and $\mathrm{K}_{1}$ is $300 \mathrm{ksf} / \mathrm{ft}$.

\subsubsection{Soil Profile and Dynamic Soil Properties}

An idealized soil profile for the TEF project is shown in Figure 5, along with the unit weight, shear wave velocity and Poisson's ratio for each layer. The elevation of the water table is 260 feet. The normalized shear modulus and damping are functions of shear strain as shown in Figures 6 and 7. The shear modulus, G, is given by the relationship

$$
\frac{\mathrm{G}}{\mathrm{G}_{\max }}=\frac{1}{1+\frac{\varepsilon}{\varepsilon_{\mathrm{ref}}}}
$$

where $\quad G_{\max }$ is the low strain shear modulus, which is calculated from the shear wave velocity, $\varepsilon$ is the soil shear strain, and $\varepsilon_{\text {ref }}$ is the reference strain given in Table 9. .

Damping values at different strain levels are given in Table 10. Soil at the TEF facility is consistent with UBC soil profile type $S_{d}$. 


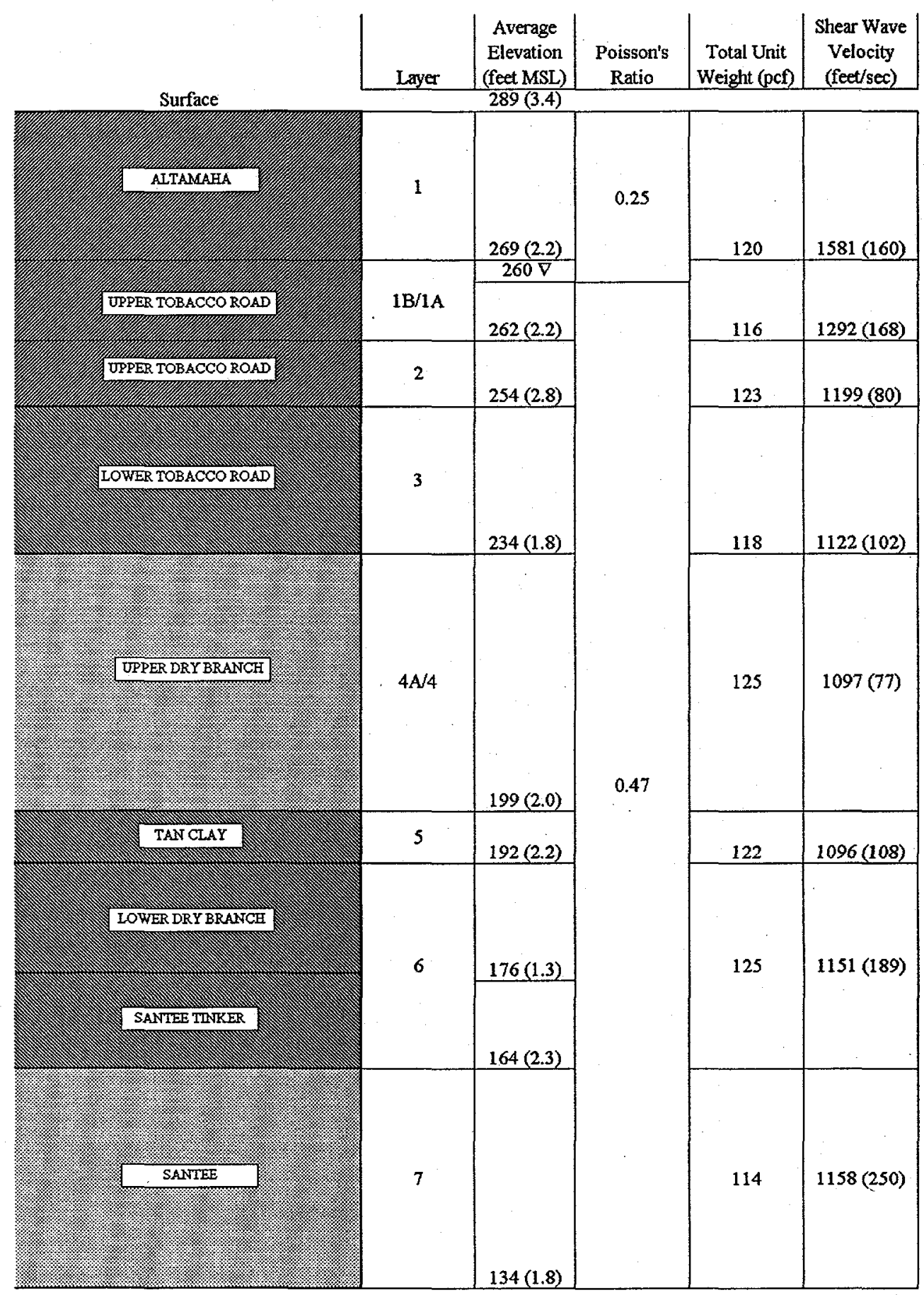

1. Numbers shown are average values

2. Numbers in parantheses are standard deviations

Figure 5 Idealized Soil Profile [11] 


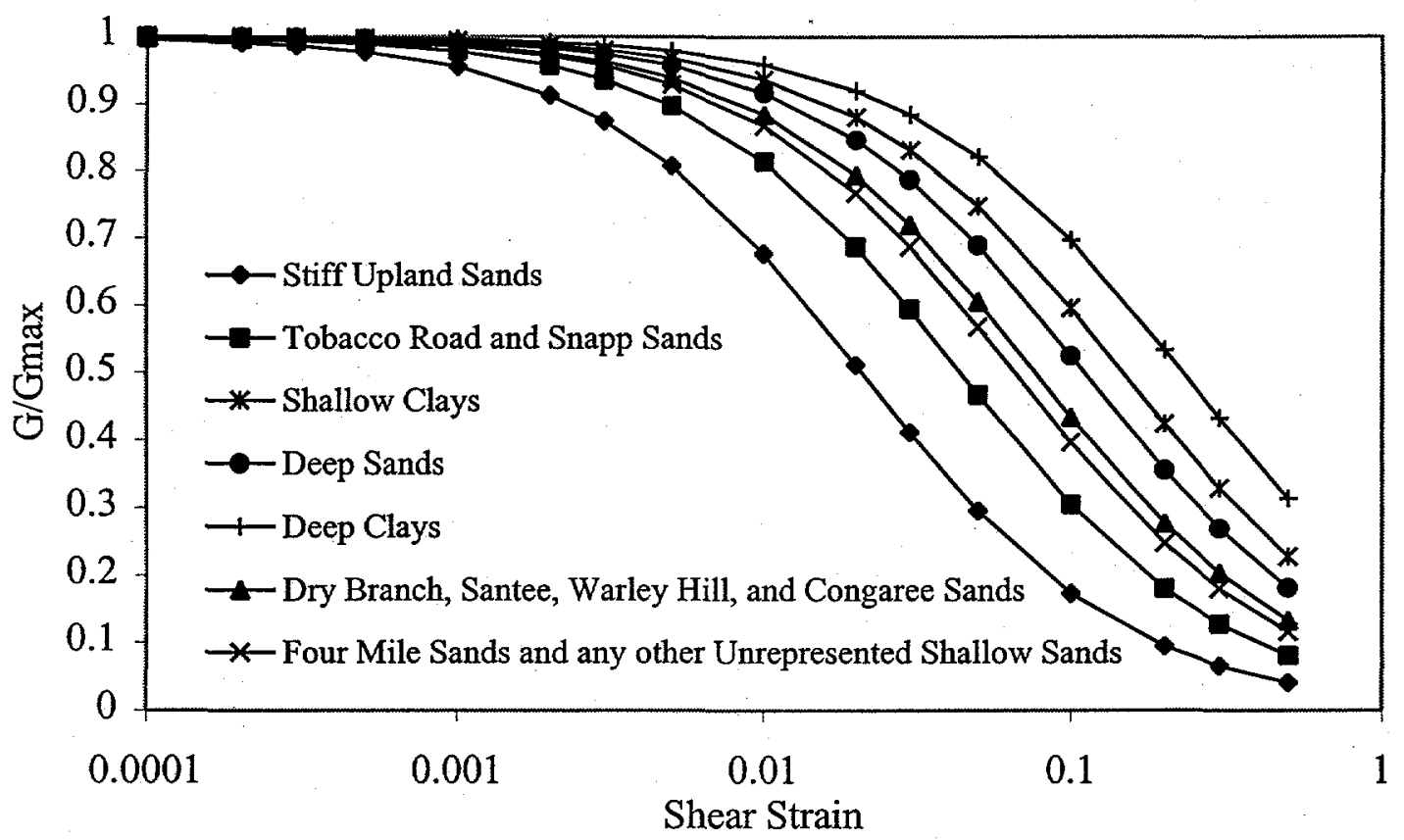

Figure 6 Soil Shear Stiffness

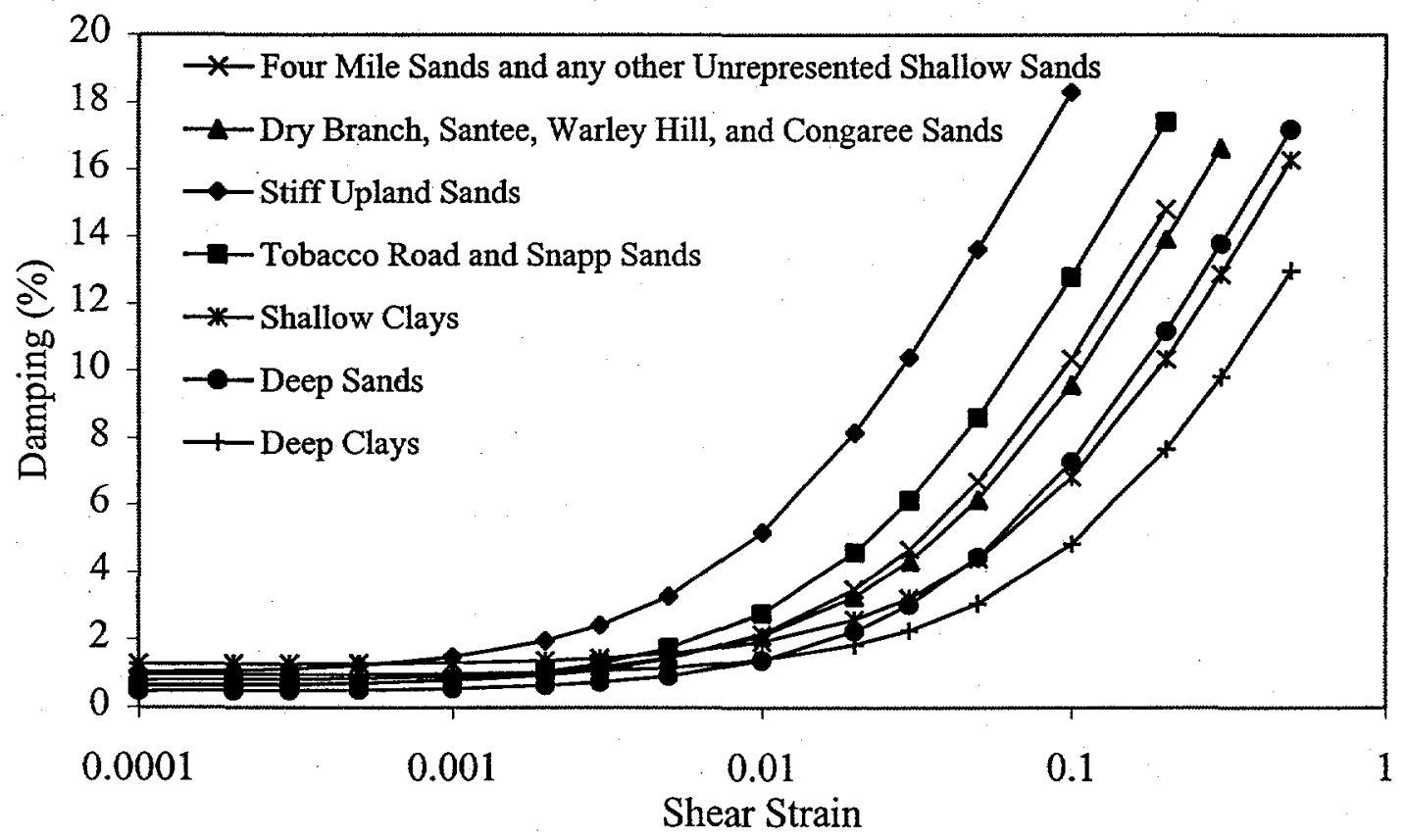

Figure 7 Soil Damping [11] 
Table 8 Reference Strain For Soil Layers [11]

\section{Formation Description}

Stiff Upland Sands

Tobacco Road and Snapp Sands

Dry Branch, Santee, Warley Hill, and Congaree Sands

Four Mile Sands and any other Underrepresented Shallow Sands

Shallow Clays

Deep Sands

Deep Clays

Reference Strain
$\varepsilon_{\text {ref }}(\%)$
0.021
0.044
0.077
0.066
0.148
0.111
0.230

Table 9 Damping Vs. Shear Strain [11]

\begin{tabular}{|c|c|c|c|c|c|c|}
\hline \multirow{2}{*}{$\begin{array}{c}\text { Strain } \\
(\%)\end{array}$} & & \multicolumn{5}{|c|}{ Formation } \\
\hline & $\mathbf{A}$ & B & C & $\mathrm{D}$ & $\mathbf{E}$ & $\mathbf{F}$ \\
\hline 0.00001 & 1.059 & 0.625 & 0.825 & 0.674 & 1.296 & 0.489 \\
\hline 0.0001 & 1.059 & 0.625 & 0.825 & 0.674 & 1.296 & 0.489 \\
\hline 0.0002 & 1.103 & 0.647 & 0.835 & 0.687 & 1.292 & 0.497 \\
\hline 0.0003 & 1.151 & 0.670 & 0.846 & 0.702 & 1.293 & 0.505 \\
\hline 0.0005 & 1.248 & 0.717 & 0.871 & 0.733 & 1.300 & 0.524 \\
\hline 0.001 & 1.493 & 0.835 & 0.936 & 0.811 & 1.326 & 0.570 \\
\hline 0.002 & 1.973 & 1.070 & 1.070 & 0.970 & 1.389 & 0.665 \\
\hline 0.003 & 2.434 & 1.300 & 1.205 & 1.127 & 1.456 & 0.759 \\
\hline 0.005 & 3.302 & 1.747 & 1.470 & 1.435 & 1.594 & 0.945 \\
\hline 0.01 & 5.201 & 2.790 & 2.108 & 2.171 & 1.938 & 1.398 \\
\hline 0.02 & 8.165 & 4.605 & 3.281 & 3.505 & 2.603 & 2.251 \\
\hline 0.03 & 10.407 & 6.139 & 4.336 & 4.686 & 3.233 & 3.039 \\
\hline 0.05 & 13.639 & 8.614 & 6.162 & 6.692 & 4.392 & 4.453 \\
\hline 0.1 & 18.317 & 12.799 & 9.605 & 10.363 & 6.820 & 7.289 \\
\hline 0.2 & & 17.425 & 13.951 & 14.825 & 10.356 & 11.179 \\
\hline 0.3 & & & 16.683 & & 12.884 & 13.799 \\
\hline \multicolumn{2}{|l|}{0.5} & & & & 16.317 & 17.210 \\
\hline \multicolumn{7}{|c|}{ Formation Description: } \\
\hline A & \multicolumn{6}{|c|}{ Stiff Upland Sands } \\
\hline B & \multicolumn{6}{|c|}{ Tobacco Road and Snapp Sands } \\
\hline $\mathrm{C}$ & \multicolumn{6}{|c|}{ Dry Branch, Santee, Warley Hill, and Congaree Sands } \\
\hline $\mathrm{D}$ & \multicolumn{6}{|c|}{ Four Mile Sands and any other Underrepresented Shallow Sands } \\
\hline $\mathrm{SH}$ & \multicolumn{6}{|c|}{ Shallow Clays } \\
\hline $\mathrm{D}$ & \multicolumn{6}{|c|}{ Deep Sands } \\
\hline \multicolumn{7}{|c|}{ Deep Clays } \\
\hline
\end{tabular}




\subsection{Reinforced Concrete}

The nominal concrete strength is 4000 psi with an elastic modulus of $\mathrm{Ec}=57000 \sqrt{\mathrm{f}^{\prime} \mathrm{c}}=3600 \mathrm{ksi}=520,000 \mathrm{ksf}$. Poisson's ratio for concrete is 0.20 and the shear modulus is $\mathrm{Gc}=217,000 \mathrm{ksf}$.

Reinforcing Steel shall be either ASTM A615 Grade 60 or A706. A706 reinforcing steel shall be used at locations where rebar welding is anticipated. Welding of reinforcing steel shall be in accordance with the Structural Welding Code Reinforcing Steel, AWS D1.4 [9]. Reinforcing properties are summarized in Table 10. The elastic modulus of reinforcing steel is $29,000 \mathrm{ksi}$.

\section{Table 10 Reinforcing Steel Mechanical Properties}

$\begin{array}{lcc} & \begin{array}{c}\text { A615 } \\ \text { Grade 60 }\end{array} & \text { A706 } \\ \text { Minimum yield, ksi } & 60 & 60 \\ \text { Maximum yield, ksi } & & 78 \\ \text { Minimum ultimate, ksi } & 90 & 80 \text { but not less than } 1.25 \text { fy } \\ \text { Minimum elongation in 8 inches, \% } & & \\ \text { \#3-\#6 } & 9 & 14 \\ \# 7-\# 8 & 8 & 12 \\ \# 9-\# 11 & 7 & 12 \\ \# 14, \# 18 & 7 & 10\end{array}$

Damping for lightly loaded reinforced concrete structures shall be taken at $4 \%$ critical, while damping for moderately and heavily loaded structures shall be taken as $7 \%$ and $10 \%$ critical respectively. Lightly loaded structures have a demand ( $\mathrm{F} \mu=1)$ less than $50 \%$ of the capacity while moderately loaded structures have a demand $(\mathrm{F} \mu=1)$ less than the capacity. The structural loads may be established using $10 \%$ damping [1]. However, the appropriate damping level shall be used to develop instructure response spectra.

\subsection{Structural Steel}

ASTM A572 Grade 50 structural steel shall be used with a minimum yield of $50 \mathrm{ksi}$ and a minimum ultimate strength of $65 \mathrm{ksi}$. Welding of structural steel shall be performed in accordance to AWS D1.1 [16], using E-70XX electrodes. Bolted structural joints shall use ASTM A325 Bolts, while either A307 or ASTM A193 B7 anchor bolts shall be used. 


\section{ANALYSIS PROCEDURES}

The building structure shall be evaluated for component forces due to loads specified in Section 4, load combinations specified in Section 5, and the material properties specified in Section 6. The demands calculated following the procedures in this section are compared to the capacities calculated in accordance with Section 8.

The criteria allow the use of classical solutions based on a linear elastic analysis, yield line analysis and finite element analysis as appropriate to determine the structural demand. Finite element models shall be of sufficient detail to capture the predominant structural responses. ASCE 4-86 "Seismic Analysis of Safety Related Nuclear Structures" [6] will be used for modeling guidance.

\subsection{Operating Loads}

The building analysis for operating loads is intended to provide bounding element forces and deflections for member design. Simple beam strips and two dimensional frames shall be used to quantify member forces and deformations. The basemat may be analyzed using either beam strips or as a two dimensional plate. Two way plates, which are idealized as beams for the purposes of analysis, shall be reinforced in the second direction.

Lateral earth pressure for soil shall be based on the at-rest soil pressure and include the incremental lateral soil pressure due to compaction. Uniform surcharge loads shall be added to the weight of the soil column. Lateral soil pressure from adjacent concentrated surface loads shall be taken as twice the lateral load from Boussinesq solution for a linear elastic half space.

The building will not be evaluated for the effects of heave since the soil will recompress during construction. It is acknowledged that the heave and recompression process may lock stresses into the building during construction. However, the effect of these stresses on the building's ultimate strength will be negligible since the building will be detailed to behave in a ductile manner.

Heave, recompression and settlement can damage Systems, Structures and Components (SSC) that span between adjacent buildings. These effects will be addressed by monitoring the building settlement during construction and installing these SSC after the rate of settlement reach a tolerable level.

\subsection{Seismic Inertial Loading}

Seismic inertial loads shall be evaluated by dynamic analysis incorporating SoilStructure-Interaction (SSI) effects. 


\subsubsection{Seismic Input}

\section{Free Field Response Spectra}

Free field acceleration response spectra is the seismic input specified in Section 4 . The $2-7 \%$ damped spectrum shape shall be used as seismic input for both horizontal and vertical seismic analyses.

\section{Time Histories}

Acceleration time histories will be developed for the seismic analysis and will be specified in the free field. The time history shall envelop its corresponding target spectrum in accordance with the following criteria for each spectral damping value of interest. Time histories for use in orthogonal directions, shall be statistically independent with a cross correlation coefficient less than 0.30 [6].

The time interval, $\Delta t$, between acceleration data points shall be less than or equal to 0.01 seconds or $1 /\left(10 f_{\max }\right)$ seconds, where $f_{\max }$ is the highest frequency of interest. The time histories developed shall be baseline corrected prior to their use in SSI analyses.

The criteria for enveloping the input spectra are as follows:

1. The frequency increments will be determined consistent with ASCE 4-86 criteria.

2. The spectra computed from the time histories shall not dip below the target spectra at more than five computed frequencies by more than ten percent.

3. The time interval for the input time histories will be chosen to retain the cut-off frequency, but not greater than 0.01 second.

4. The duration of the ground motion is given in Table 6 .

5. A quiet zone of trailing zeros will be appended to the time histories for the frequency domain SSI analysis, which uses fast Fourier transforms.

\section{Horizontal Spatial Variation of Free Field Motion}

Horizontal spatial variations of ground motion result from nonvertically propagating waves and incoherence of the input motion. This is a result of refraction and reflections as the earthquake wave passes through the underlying heterogeneous geological material. These phenomena are generally taken into consideration for very large structures, such as long multiple span bridges [21], and are not considered in this criteria.

\subsubsection{Dynamic Soil Modeling}

\section{Best Estimate Soil Properties}

The site will be modeled as a series of infinite visco-elastic horizontal layers over a semi-infinite visco-elastic half-space. The soil properties required for a dynamic analysis are shear modulus or shear wave velocity, 
Poisson's ratio, unit weight, and material damping. The average low strain soil column in Figure 5 represents the best estimate of the soil properties.

\section{Variation in Soil Shear Modulus}

Three soil profiles will be considered to account for yariations in the shear modulus of soil: best estimate, upper bound, and lower bound. This variation will be determined by multiplying the best estimate shear modulus values by $(1+\mathrm{Cv})$ to obtain the upper bound, and dividing the best estimate shear modulus values by $(1+\mathrm{Cv})$ to obtain the lower bound. The coefficient of variation, $\mathrm{Cv}$, of the soil column in Figure 5 ranges between 0.067 and 0.216 while ASCE 4-86 requires a minimum $\mathrm{Cv}$ of 0.5 . This analysis follows the guidance of ASCE 4-86.

\section{Strain Dependency of Soil Properties}

The variation of the soil modulus and hysteretic damping with shear strain will be considered using the site-specific material properties in Section 6.

\section{Deconvolution}

The main response of the system are caused by the vertically propagation of body waves from an under-laying rock formation. The SHAKE computer program [23] will be used to obtain shear modulus and damping values compatible with the effective strains in the layered soil system for the vertical propagation of body waves. The following criteria shall be followed for this analysis:

- The control motions specified at the free surface shall be the horizontal motions developed above and are assumed to be vertically propagating, horizontal shear waves.

- The elastic half space will be placed far enough below the foundation level such that the seismic response of the structure is not significantly affected. The half space may be placed at a depth equal to the length of the structure below the base mat.

- The soil layer thickness shall be determined to ensure frequency transmitting characteristics up to the analysis cut-off frequency $\left(f_{\max }\right)$. Layer thickness will not significantly exceed Vs/ $\left(5 \mathrm{f}_{\max }\right)$, where Vs is the lowest shear wave velocity of the layer, reached during iterations, for the soil condition considered in the analysis.

\subsubsection{Structural Properties}

The overall mass and stiffness properties of the building and hence the primary dynamic behavior, shall be represented in the SSI models. The reduction of stiffness due to concrete cracking shall be considered if significant.

The effects of uncertainties in the stiffness properties of the structure and soil will be obtained from the largest computed response considering the following cases: 1. Best estimate structural model and best estimate soil properties. 
2. Best estimate structural model and lower bound soil properties.

3. Best estimate structural model and upper bound soil properties.

\subsubsection{SSI Analysis}

The important SSI effects in the RHB to be considered in the SSI evaluation are:

- The shift in structural frequency due to soil stiffness;

- The relative motion between the RHB and the Tritium Processing Building; and,

- The effects of building embedment on both soil stiffness and input motion.

- Coupling of north-south and east-west lateral motions in the building due to unsymmetrical mass and stiffness along with the effects of rocking on both lateral and vertical loads.

\section{$\underline{S A S S I}$}

The soil structure interaction analysis will be performed with SASSI [12] and verified by lumped parameter spring analyses.

The dynamic models used in SASSI analyses consist of three parts: a free field model, a model of the excavated soil and a model of the building.

\section{Free Field Model}

The free field model represents the semi-infinite soil layers used in the deconvolution analysis. For horizontal seismic analyses, the soil layering and high strain soil properties shall be those specified in the deconvolution analyses. For seismic analyses for vertical motion (compression waves) the constrained modulus shall be used.

Poisson's ratio for soil both above and below the water table is given in Section 6. Below the water table, use the smaller of the Poisson's ratio in Section 6 or the Poisson's ratio that corresponds to P-wave velocities of 5000 fps.

\section{Excavated Soil Model}

The excavated soil is modeled using solid elements with nodes located at the layer interfaces of the free field model. Unless justified, the spacing between these nodes will not exceed $\mathrm{Vs} /\left(5 \mathrm{f}_{\max }\right)$. The dynamic properties of the solid elements of the excavated soil model will be identical to those described for the free field model. The excavated soil model is connected to the structural model only at the nodes located at the soil-structure boundaries. 


\section{Building Model}

A simple stick model will be used to couple the lateral response in the north-south and east-west directions. Dynamic models for the building shall be developed to reflect the predominant structural response and to capture the seismic response parameters of primary interest. Nonsymmetric geometry and mass distributions shall be considered in sufficient detail.

Vertical response will be determined using a one dimensional stick model with slabs represented by a spring-dashpot system. If significant, the vertical component of rocking from the lateral load analysis will be added to the vertical ground motion.

\section{Soil-Structure Interaction Model}

The SSI model is a combination of the structural model, the free field model, and the excavated soil model. The mass of supported equipment shall be included and may be lumped directly to the structure when the dynamic coupling requirements of ASCE 4-86 are satisfied.

The control motion is specified as the free field motion and is input at the surface.

\section{Combination of Motion}

For seismic loading where time history analysis is performed, an individual demand shall be obtained from the dynamic analyses of three statistically independent earthquake inputs, one vertical and two mutually perpendicular horizontals.

The time history in any component direction shall be the algebraic sum of the components of three time histories (one vertical and two mutually perpendicular horizontal) in that direction.

The seismic demand in any direction shall be the envelope of the demands for the three soil conditions, e.g., LB, BE and UB. The change of sign, if applicable, shall be considered.

\section{Validation of Structural Response}

The dynamic soil stiffness, acceleration of the superstructure and structural demands calculated using SASSI shall be verified with a lumped parameter spring solution.

\section{Fixed Base Check}

The SSI structural response will be checked by a fixed base analysis using the free field ground motion. The structure shall be designed to the larger of the fixed base, or SSI analysis forces. In-structure response spectra shall be based on the SSI analysis as discussed below. 
Inelastic Energy Absorption Factor, $F \mu$

Seismic inertial forces may be modified by the inelastic energy absorption factor, $\mathrm{F}_{\mu}$, as specified in DOE-STD-1020 [1].

Structure-Soil-Structure Interaction

Structure-soil-structure interaction is the dynamic response coupling of adjacent structures through the soil. The effect of interacting structures shall be considered.

The largest potential for structure-soil-structure interaction exists between the RHB and the processing building. Of the two structures the RHB is by far the heavier and may tend to drive the lighter processing building. Since the mass and stiffness of the processing building are relatively small, structure-soil-structure interaction will neglect the mass and stiffness of the processing building. The amplification of the free field ground motion in the region occupied by the processing building will be determined by calculating the surface response adjacent to the RHB in the RHB SASSI analysis. This modified surface motion will be used in the design of the processing building if it is larger than the free field ground motion.

\subsubsection{Combination of Seismic Loads}

The effect of seismic loads from different components of ground motion shall be combined at each time step. Alternately, the maximum loads may be combined with the $100 \%, 40 \%, 40 \%$ rule from ASCE $4-86$.

\subsubsection{In-Structure Response Spectra}

Most, if not all, of the equipment in the RHB has a small mass relative to the supporting structure and will have negligible interaction on the support structure and will need to be included only in the structural mass. For such equipment or subsystems meeting the decoupling requirements of ASCE 4-86 a separate analysis, outside the scope of this criteria, will be performed using the design response spectra or time history excitations at the equipment support locations derived from the SSI analysis of the supporting structure.

\section{Development of In-Structure Response Spectra}

The three components of the earthquake motion will be considered when developing the response spectra. An individual response spectrum shall be obtained from the dynamic analyses of three statistically independent earthquake inputs, one vertical and two mutually perpendicular horizontal motions. Each direction response time history shall be the algebraic sum of the responses in that direction from the results of the three response time histories. The resultant response acceleration time history is used to generate the response spectra for that direction, for the soil condition for which the three analyses were performed. Three response spectra shall be obtained for the three soil conditions, namely the lower bound, best estimate and upper 
bound. A single response spectra for that direction shall be obtained by enveloping the three spectra and smoothing and broadening.

\section{Damping Requirement}

The response spectra will be generated for damping ratios of $2 \%, 4 \%, 5 \%$ $7 \%$ and $10 \%$. If the damping value of a subsystem lies between these damping values, then linear interpolation, in accordance with ASCE 4-86, can be used to determine the intermediate value.

\section{Smoothing Response Spectra and Broadening}

To account for uncertainties in the structural frequencies owing to uncertainties in such parameters as the material properties of the structure and soil, damping values, soil structure interaction techniques and the approximations in the modeling techniques used in the seismic analysis, each computed floor response spectra from the floor time history motions will be smoothed, and the peaks associated with each of the structural frequencies broadened $0.15 f_{i}$ on either side of the frequency, where, $f_{i}$ corresponds to the frequency of the structural peak. In conjunction with response-spectra broadening, the peak amplitude shall be reduced by $15 \%$ [6].

\subsection{Post Seismic Differential Settlement}

Post seismic differential settlement shall be evaluated by pseudo-static analysis.

Soft zone subsidence can result in localized settlement regions (LSR) under the basemat. Geotechnical investigations have determined that the LSR is about 40' in diameter [11]. To provide for a robust design of the RHB, (1) the size of the LSR shall be postulated to have a diameter equal to the RHB building width; and (2) the LSR shall be postulated to occur at any location under the RHB basemat.

Liquefaction can also result in differential settlement under the basemat. SRS Site Geotechnical Services has recommend that the differential settlement due to liquefaction be applied to the remote handling building over the width of the basemat (70 feet). The location of the liquefaction differential settlement profile is postulated to occur at any location under the basemat and is independent of the location of soft zone subsidence. To enhance the robustness of the RHB, the maximum differential settlement across the TEF site is assumed to occur under the base of the RHB. Given that the maximum liquefaction settlement in the TEF site is 3 inches and the range of liquefaction settlement under RHB is $1 / 2$ " to 1 ", then the TEF RHB design differential settlement is taken as $2 \frac{1}{2} "$.

The basemat shall be sized to span over both the LSR and the liquefaction differential settlement profile. Vertical soil forces acting upward on the basemat shall be determined by neglecting the flexibility of the basemat. Rigid body rotation of the 
building and the soil subgrade modulus may be used to redistribute soil forces. The basemat may be analyzed either as part of a unit-width beam strip or as a two-way plate which carries the floor loads and spans over settled region(s). Reinforced concrete walls may be used to stiffen the basemat.

\subsection{Impact Loads}

Impact loads acting on structures shall be evaluated in accordance with the guidance of ASCE A-58[24]. Both global collapse and local effects shall be considered separately. The local effects analysis shall address spalling, scabbing and penetration.

DOE -STD-1020 [1] recommends the following Tornado missile Barriers for PC3 structures, shown in Table 11. Barriers larger than those shown in Table 11, need not be analyzed for Tornado missiles.

Table 11 : Recommended Tornado Missile Barriers For PC3 Structures

\begin{tabular}{|c|c|}
\hline Missile Criteria & Recommended Missile Barrier \\
\hline $\begin{array}{l}\text { Horizontal } \\
\text { Component: }\end{array}$ & $\begin{array}{l}7 \text { inn CMU wall with one \#4 rebar grouted in each vertical cell and } \\
\text { trussed horz joint reinf@ } 16 \text { in on center }\end{array}$ \\
\hline $2 \times 4$ timber plank & Single width brick veneer attached to stud wall with metal ties \\
\hline $\begin{array}{l}\text { max. height } 150 \mathrm{ft} \\
\text { above ground }\end{array}$ & $\begin{array}{l}4 \text { in concrete slab with \#3 rebar @ } 6 \text { in on center each way in middle of } \\
\text { slab }\end{array}$ \\
\hline $\begin{array}{l}\text { Vertical Component: } \\
2 \times 4 \text { timber plank } \\
15 \mathrm{lb} @ 70 \mathrm{mph}\end{array}$ & $\begin{array}{l}4 \text { in concrete slab with \#3 rebar @ } 6 \text { in on center each way in middle of } \\
\text { slab }\end{array}$ \\
\hline \multirow{2}{*}{$\begin{array}{l}\text { Horizontal } \\
\text { Component }\end{array}$} & $\begin{array}{l}12 \text { in CMU wall with \#4 rebar in each vertical cell and grouted; \#4 rebar } \\
\text { horizontal @ } 8 \text { in on center }\end{array}$ \\
\hline & $\begin{array}{l}\text { Nominal } 12 \text { in wall consisting of } 8 \text { in CMU with \#4 rebar in each } \\
\text { vertical cell and grouted; } \# 4 \text { rebar horizontal @ } 8 \text { in on center; single } \\
\text { wythe brick masonry on outside face; horizontal ties @ } 16 \text { in on center. }\end{array}$ \\
\hline $\begin{array}{l}3 \text { in diameter } \\
\text { steel pipe } 75 \mathrm{lb} \\
\text { @ } 50 \mathrm{mph}\end{array}$ & $\begin{array}{l}9.5 \text { in reinforced brick cavity wall with \#4 rebar @ } 8 \text { in on center each } \\
\text { way in the cavity; cavity filled with } 2500 \text { psi concrete; horizontal ties @ } \\
16 \text { in on center }\end{array}$ \\
\hline above ground & $\begin{array}{l}8 \text { in concrete slab with } \# 4 \text { rebar @ } 8 \text { in on center each way placed } 1.5 \text { in } \\
\text { from each face }\end{array}$ \\
\hline $\begin{array}{l}\text { Vertical Component : } \\
3 \text { in diameter steel } \\
\text { pipe75 lb @35 mph }\end{array}$ & $\begin{array}{l}6 \text { in concrete slab with \#4 rebar @ } 12 \text { in on center each way } 1.5 \text { in from } \\
\text { inside face }\end{array}$ \\
\hline
\end{tabular}




\section{STRUCTURAL ACCEPTANCE CRITERIA}

\subsection{General}

The demand on a structural concrete element is the maximum force or displacement, resulting from the analyses specified in section 7.0 and from load combinations defined in section 5.0. If the demands on a structure are less than its corresponding capacity, for all applicable load combinations, then the structure shall be considered acceptable.

\subsection{Reinforced Concrete}

The requirements of ACI 349 [4] are generally based on ACI 318 [3] and typically lag several years behind ACI 318 criteria. Thus, the more current ACI 318 criteria are chosen for the design of the RHB. However, ACI 349 has explicit limits on operating temperature, minimum reinforcement, design guidance for embedment and anchorage, and more restrictive displacement criteria than ACI 318. These criteria are adopted from ACI 349 for use in the RHB design.

The design of reinforced concrete structural elements, including their capacity calculations shall be in accordance with the provisions of ACI 318-99 [4] except as listed below.

- The minimum reinforcing requirements of ACI 349 Section 7.12 shall replace the shrinkage and temperature reinforcement requirements of ACI 318 Section 7.12.

Discussion: ACI-349 Section 7.12 generally requires more reinforcing than $A C I-318$ Section 7.12. Just as important, $A C I-349$ requires that the minimum reinforcement for walls and slabs shall be applied at each face. On the tension face of slabs, walls and shells, the minimum reinforcing required by $A C I-349$ is equal (assuming Grade 60 rebar) to the total minimum steel that $A C I-318$ requires.

ACI-349 also has special provisions for special shrinkage and temperature reinforcement in mass concrete.

- The requirements to assure ductility in ACI-349 Section C.4.3 shall replace the requirements for structural integrity in ACI 318 Sections 7.13.2.

Discussion: The impact criteria in ACI 349 Appendix C has ductility requirements, which are adopted to protect against unanticipated loading. These ductility requirements are more stringent than ACI 318 Section 7.13.2. The remaining ductility requirements of $A C I-349$ Section $C .4$ are enveloped by the seismic detailing requirements discussed below. 
- The temperature limits of ACI 349 Appendix A.4 shall apply.

Discussion: ACI-318 does not provide temperature limits to protect concrete against thermal degradation.

- ACI 349 Section 7.5 shall apply instead of ACI 318 Section 7.5

Discussion: $A C I-349$ provides placement tolerances for deep sections while ACI-318 requires that the same tolerances on deep sections as intermediate sections. The ACI-349 placement tolerances are more appropriate for the thick walls and slabs in the remote handling building.

- Steel embedment and anchorage shall be designed in accordance to ACI-349 Appendix B.

Discussion: ACI-318 does not provide embedment and anchorage design.

- The control of deflection requirements in ACI 349 Section 9.5 shall replace ACI 318 Section 9.5 .

Discussion: $A C I-349$ provides more stringent deflection criteria than $A C I-$ 318. The deflection criteria in ACI-349 was developed to support equipment operability in nuclear facilities while the deflection criteria of ACI-318 was developed to support commercial building (office) operation. The ACI-349 criteria is more appropriate for the remote handling building.

- The special provisions for seismic design in ACI 318 Section 21, shall be replaced by the special provisions for seismic design in ACI 349 Section 21.

Discussion: ACI 318, ACI 349 and Uniform Building Code (UBC) [25] were considered for the seismic detailing requirements. Both $A C I 349$ and $U B C$ criteria are based on ACI 318. ACI 318 and the UBC codes have graded seismic detailing requirements. ACI 349 unilaterally applies the high seismicity detailing requirements to provide additional assurance that structural integrity is maintained, and to provide bar detailing requirements that are consistent with DOE seismic design criteria. Note that DOE-STD1020, which refers to UBC for seismic detailing was published before ACI 349 adopted special provisions for seismic design.

The criteria in ACI 349 are intended for shear wall and slab construction of generally heavy proportions. In the RHB, the primary lateral load resisting system is a low-rise R/C box system with massive (approx. 5' thick) shear walls. All three codes provide identical in-plane shear capacities for the walls. The primary difference between the codes is in the application of boundary element reinforcing. ACI 318 requires boundary elements for all 
shear walls with greater than $0.2 f^{\prime \prime} c$ compressive stress on the extreme fiber. $U B C$ requires boundary elements for shear walls unless they have a low axial load and a height to width ratio less than one. ACI 349 requires boundary elements when the height to width ratio is greater than two. For walls with a height to width ratio less than two, the commentary of ACI 349 states that the walls are dominated by shear, and that boundary elements, which are provided for flexural ductility and confinement are not required.

It is important to note that both $A C I-318$ and UBC seismic detailing criteria were developed for commercial construction where tall narrow flexural-shear walls are typical. On the contrary, ACI-349 was developed for nuclear facilities where short squat shear walls are typical. Thus, the seismic detailing requirements of $A C I-349$ are most appropriate for the remote handling building design.

\subsection{Structural Steel}

The capacity of structural steel members shall be determined in accordance with AISC Load and Resistance Factor Design (LRFD) Manual of Steel Construction [7]. The following additional restrictions also apply:

- All members shall be compact sections.

- Connections shall be proportioned such that failure, due to an overload, shall occur in the member.

- The steel crane runway girders shall be designed in accordance with the AISE Technical Report No. 13 [10].

- The effective length of stepped crane columns shall be determined in accordance with the AISE Technical Report No. 13 [10].

\subsection{Miscellaneous Structural Elements}

\subsubsection{Slab and Wall Moment Frame Detailing Requirements}

Reinforced concrete slab and wall moment frames shall meet the detailing requirements for flexural members of frames in ACI 349-97 Section 21.3. Except, that stirrups need only be provided if required for out-of-plane shear. Reinforcing bars in slab and wall moment frames shall be developed in accordance with ACI 349-97 Section 21.5.4. The detailing requirements for structural walls and diaphragms ACI 349-97 Section 21.6 shall be met for inplane forces.

\subsubsection{Cell Covers}

Steel and concrete cell covers shall meet the requirements of the preceding sections and the following additional requirements.

- Cell covers shall be proportioned to behave in a ductile manner if overloaded. 
- Longitudinal reinforcing in concrete cell covers shall be anchored at the ends of the cell cover.

- The cell cover shear capacity and supporting structure shall be proportioned to resist $125 \%$ of the load causing yield in the cell cover's longitudinal reinforcing.

\subsubsection{Crane Runway Lateral Support}

Reinforced concrete elements, which support crane runways, shall have lateral ties around crane rail anchor bolts. The lateral ties shall be proportioned to develop the shear capacity of the anchor bolt, and shall be located not less than 3 inches below the crane rail sole plate.

\subsubsection{Lifting Lugs}

Lifting lugs shall have a minimum factor of safety of three on yield and five on ultimate strength. 


\section{REFERENCES}

1. DOE-STD-1020, "Natural Phenomenon Hazards Design and Evaluation Criteria for Department of Energy Facilities".

2. Structural Design Criteria, Engineering Standard 01060, Draft Rev 4, Savannah River Site, September, 1999.

3. ASCE 7-95, "Minimum Design Loads for Buildings and Other Structures", American Society of Civil Engineers

4. ACI 318-99, "Building Code Requirements for Structural Concrete".

5. ACI 349-97, "Code Requirements for Nuclear Safety Related Concrete Structures".

6. ASCE Standard 4-86, "Seismic Analysis of Safety Related Nuclear Structures and Commentary on Standard for Seismic Analysis of Safety Related Nuclear Structures", American Society of Civil Engineers.

7. Manual of Steel Construction, Load \& Resistance Factor Design, Volume I and II, Second Edition.

8. DOE Order 420.1 Change 2, "Facility Safety" 10/24/96.

9. ANSI/AWS D1.4-98, "Structural Welding Code-Reinforcing Steel," American Welding Society, 1998.

10. AISE Technical Report No. 13, Guide for the Design and Construction of Mill Buildings, Association of Iron \& Steel Engineers, 1991.

11. K-ESR-H-00010, Rev 1, December 1998, "Commercial Light Water Reactor, Tritium Extraction Facility, Geotechnical Summary Report", WSRC.

12. SASSI, "A System for Analysis of Soil Structures Interaction”, J. Lysmer, et al, 1981, University of California, Berkeley.

13. G-ESR-H-00023 Rev A, "Remote Handling Building Loads Study", 8-18-99.

14. C-SYD-H-00002 Rev. 4, "Civil/Structural Systems, System Design Description For Build and Cell Structures, Project No. S-6091," WSRC, July 31, 1998.

15. WSRC-TR-99-00369, "Flood Hazard Recurrence Frequencies for C-, F-, E-, S-, H-, Y- and Z-Areas (U), 1999.

16. ANSI/AWS D1.1-98, "Structural Welding Code-Steel," American Welding Society 1998.

17. Draft Revision to ASCE Standard 4-86, "Seismic Analysis of Safety Related Nuclear Structures and Commentary on Standard for Seismic Analysis of Safety Related Nuclear Structures", American Society of Civil Engineers, April 24, 1997.

18. DOE-HDBK-1132-99. "DOE Handbook-Design Considerations," April 1999.

19. Lambe, T.W., and Whitman, R.V., "Soil Mechanics," Wiley, 1969.

20. PECD-SGS-99-0138, "Final Compaction Induced Lateral Earth Pressure Distribution for TEF," September 23, 1999.

21. Clough and Penzien, "Dynamics of Structures Second Edition," McGraw-Hill, 1993.

22. T-CLC-G-00119, Rev. 0, "Generation of PC3 Acceleration Time Histories for SRS-STD 01060 Rev. 4", 1999.

23. SHAKE-91, "A Computer Program For Conducting Equivalent Linear Seismic Response Analyses of Horizontally Layered Soil Deposits," I.M. Idress, et al, 1992.

24. ASCE Manual No. 58 "Structural Analysis and Design of Nuclear Plant Facilities," 1980.

25. Uniform Building Code, International Conference of Build Code Officials, 1997. 


\section{Distribution:}

John Hurd, 730-1B/134

Dennis Niehoff, 730-1B/1010

Frank Keelty, 730-1B/2094

Bob Royer, 730-1B/1045

Mike Lewis, 730-2B/116

Mike Wallick, 730-1B/1004

George Vozniak, 730-1B/128

Steve Clark, 730-1B/1036

Ron Fayfich, 730-1B/1007

Larry Salomone, $730-2 B / 130$

Henry King, 730-1B/1041
Fred Loceff, 730-1B/319

Greg Mertz, 730-1B/314

Ranjit Bandyopadhyay, 730-1B/3083

Salman Khan, 730-1B/3097

Jagadish Joshi, 730-1B/3068

Emer Macaraeg, 730-1B/3084

Heather Moulton, $730-1 \mathrm{~B} / 3080$

Jay Amin, 730-1B/3069

Guy Baldwin, 730-1B/3081

Jagdish Bhatt, 730-1B/3082

Alarabi Elchoufi, 730-1B/3085 